\title{
INDUSTRI CREATIVE FUTURES MALAYSIA: MENGADILUHUNG PELUANG MENJADI LABORITORIUM DUNIA
}

\author{
ABU HASSAN HASBULLAH*
}

\begin{abstract}
Abstrak
Penulisan ini mengupas secara kritis tentang perkembangan industri kreatif di abad ke 21 dan selepasnya. Ia turut mengenalpasti peluang-peluang yang wujud dalam usaha untuk menjadikan Malaysia sebagai laboritorium dunia dalam bidang industri kreatif ini. Kreativiti tidak wujud secara sampingan dalam industri seni atau media, tetapi sebagai sentral - dan mencetuskan kepentingan - ia adalah input buat semua sektor di mana bentuk rekacipta dan kandungan wujud dalam lingkaran ekonomikal global, khususnya dengan perkembangan participatory democracy. Perkembangan ini telah mencetuskan fenomena "creative futures" Kurun 21 apabila di waktu yang sama berlakunya kepesatan berganda kemajuan dalam bidang sains dan teknologi informasi dengan terciptanya pelbagai rangkaian komunikasi dan media baru dengan internet menjadi struktur sistem penghidupan terpenting.
\end{abstract}

Kata Kunci : Industri Kreatif, Creative futures, Ekonomi Kreatif

\begin{abstract}
This writing critically reviews the development of creative industries in the 21st century and beyond to see the opportunities that exist in order to make Malaysia a laboritorium world in this creative industry. Creativity is not simply incidental in art or media industry, but as a central and sparked an interest - as an input for all sectors in which form and content design in the global economical circles, especially with the development of participatory democracy. This development has given rise to the phenomenon of "creative futures" of $21^{\text {st }}$ Century when at the same time rapid progress in science and technology is taking place with the invention of a variety of communication networks and new media with the internet becoming the most important structure of living systems.
\end{abstract}

Keywords: Creative Industry, Creative futures, Creative Economy

*PhD, Profesor dan Dekan, Fakulti Teknologi Kreatif dan Warisan, Universiti Malaysia Kelantan 


\subsection{Pendahuluan}

Pada dasarnya pertumbuhan INDUSTRI KREATIF adalah berhubungan dengan kebangkitan industri budaya, mengukuhkan signifikan pengetahuan dalam semua aspek produksi, distribusi dan konsumsi ekonomi, dan peningkatan pengaruh serta kepentingan sektor perkhidmatan. Ini terkait langsung dengan gravitas kedinamikan ekonomi baru yang ditandakan oleh pengaruh, pengukuhan dan kuasa (Castells 2000), secara kandungan disebut industri "creative futures".

"Creativity is on everyone's lips these days. Enterprises known for the most creative, innovative products and services outflank competitors by far, lucidly illustrated by globally highly respected firms like Apple, Nintendo and similarly prospering enterprises. The understanding that economic success is deeply intertwined with the fusion of creativity and technology appears to be todays' and futures' critical success factor and main key for developing internationally competitive products and services, thus striking a new path to vigorous growth and prosperity."

(MFG Baden-Wuerttemberg mbH, Public Innovation Agency for IT and Media 2009)

Kreativiti bukan secara mudah bersampingan dalam industri seni atau media, tetapi sebagai sentral - dan mencetuskan kepentingan - sebagai input buat semua sektor di mana bentuk rekacipta (design) dan kandungan (content) dalam lingkaran ekonomikal global, khususnya dengan perkembangan participatory democracy.

“... be realistic and workable. For all practical purposes, this means that they ought to be a product of actual political experience. Ccomplement and be compatible with the primary representative institutions of large-scale modern societies. Directly address liberal anxieties over such unitary propensities of participatory communities as irrationalism, prejudice, uniformity, and intolerance. Deal concretely with the obstacles that modernity appears to place in the way of participation: namely, scale, technology, complexity, and the paradox of parochialism.Give expression to the special claims of strong democracy as a theory of talk, judgment, and public seeing by offering alternatives to representation, simple voting, and the rule of bureaucrats and expert”.

(Barber 1984: 262).

Agamani industri kreatif; "activities which have their origin in individual creativity, skill and talent and which have the potential for wealth and job creation through generation and exploitation of intellectual property" (CITF 2001: 7) mula terbaca, seperti yang diperucapkan oleh John Howkins dalam The Creative Economy (2001: 87) sebaik menemukan kehadiran gelombang ekonomi kreatif buat alif kalinya di tahun 1996 bila lingkaran penghasilan karya hakcipta di Amerika Syarikat mencecah nilai jualan eksport sebanyak AS\$60.18 juta yang jauh melampaui keupayaan eksport sektor lain seperti automotif, pertanian dan pesawat termasuk teknologi 
peperangan. Industri kreatif Amerika Syarikat mendominasi secara menyeluruh gravitas ekoposial Amerika Syarikat sendiri, malah telah turut merancakkan pertumbuhan ekonomi sejagat dengan petunjuk-petunjuk pembangunan keupayaan baru dengan keseluruhan sektor inovasi kreatif seperti perfileman, televisyen, periklanan, arkitektur, seni rupa, kraftangan, rekabentuk dan rekahias, fesyen, muzik, persembahan pentas, penerbitan, permainan video dan komputer, pertunjukan hiburan, termasuk sukan dan juga penghasilan gajet-gajet yang menyokong kandungan kreatif termasuk perkakasan seperti perabut, perhiasan dan pementasan budaya yang secara keseluruhan seperti yang dilaporkan oleh Global Media \& Entertainment 2008-2012, menyatakan pendapatan daripada industri kreatif peringkat global mampu mencecah hingga AS\$2.2 trilion (RM8 trilion). Perkembangan ini telah mencetuskan fenomena "creative futures" Kurun 21 apabila di waktu yang sama berlakunya kepesatan berganda kemajuan dalam bidang sains dan teknologi informasi dengan terciptanya pelbagai rangkaian komunikasi dan media baru dengan internet menjadi struktur sistem penghidupan terpenting.

Creative Industries accounted for 7.9\% GDP in 2000; Four of the CI's account for three quarters of the economic value of the grouping of sectors (Design-2.8\% of the whole economy; Software - 1.6\%; Publishing - 0.9\%; and Advertising - 0.7\%). The CI's grew by an average of 9\% per annum between 1997 and 2000, compared to an average of $2.8 \%$ for the whole economy over this period. Exports contributed $£ 8.7$ billion to the balance of trade in 2000, equating to $3.3 \%$ of all goods and services exported. Exports have grown at around 13\% per annum over the period of 1997 2000. By comparison over the same period the value of all services exported have grown by 9\%, while all goods and services combined grew by $5 \%$.

(DCMS 2002: 4)

Pernyataan ini menyampaikan bahawa industri kreatif telah berkembang dengan pantas dan memuncak, kesan langsung dari perkembangan industri informasi dan multimedia serta internet misalnya melalui pembangunan media sosial yang menyokong participatory market sehingga mencetuskan kemampuan-kemampuan baru dalam produksi, khususnya dalam perusahaan produksi secara kecilan (pesisir) berbanding perusahaan produksi raksasa (mainstream). Ini berhubungan juga dengan peningkatan refleksivitas dalam konsumsi/pemakaian atau proses di mana pengguna secara berterusan menggunakan komoditi-komoditi kreatif dalam mengkonstruksi identiti serta berkembangnya kepercayaan pemikiran liberal relatif yang merancakkan kemauankemauan futuristik yang berasaskan pada inovasi kreativiti dan kebijakan budaya. Meski pemahaman terhadap makna, bentuk dan kandungan industri kreatif dan "creative futures", serta perbezaan-perbezaan dengan pengetahuan industri budaya yang selama ini terfaham sebagai ehwal-ehwal tentang adat, seni, tradisi, pusaka, perilaku sosial, paling tidak isu budaya seperti budaya popular dan budaya media masih lagi menjadi perbincangan di merata-rata persidangan di kalangan para sarjana, penggubal polisi termasuk para entrepreneur. 
"Adorno and Horkheimer originally coined the term cultural industry to make the distinction between the traditional artisan based creative arts and industrially produced cultural forms (Dialectic of Enlightenment). The arts were specifically not part of the cultural industries. The term 'cultural industries' which developed from this - referring to the 'classic' cultural industries of film, recorded music, broadcasting and publishing - was deployed to incorporate these forms of commercial entertainment, mass produced by industrial methods, as an object of government cultural policy".

(Galloway, Dunlop 2006: 34)

Historiografi kata dan makna industri budaya/kultural yang memajukan pemahaman industri kreatif terbit dari pertumbuhan kepercayaan terhadap komunikasi antara kandungan-kandungan yang diproduksikan bagi media-media informasi dan juga perkembangan pasaran produk-produk budaya, yang difahamkan dalam pelbagai sisi dan posisi kepentingan ekoposialnya (O'Connor 1999; Towse 2000; Cunningham 2001; Flew 2000; Hesmondhalgh 2002; Caust 2003; Hesmondhalgh \& Pratt 2005). Manakala rujukan terhadap Horkheimer dan Adorno (2002) yang mula menggunakan terma industri budaya yang merujuk pada industri hiburan komersial penyiaran, filem, muzik, penerbitan - yang terasing dari seni manakara - seni visual dan seni persembahan, muzium-muzium dan galeri-galeri. Prakarsa perusahaan media sebagai struktur baru ekoposial, dan pertumbuhan kudrat baru kapitalisme mula dibincangkan secara mendalam oleh Greater London Council (GLC) dan majlis-majlis kotaraya lain di United Kingdom sejak 1980an sehingga tertubuhnya Department Creative Industries Division (CID) dan Ministerial Creative Industries StrategyGroup (MCISG) selepas diwujudkan Creative Industries Task Force pada 1997 yang telah mendefinisikan industri kreatif/ ekonomi kreatif sebagai:

We define the creative industries as those industries which have their origin in individual creativity, skill and talent and which have a potential for wealth and job creation through the generation and exploitation of intellectual property. This includes advertising, architecture, the art and antiques market, crafts, design, designer fashion, film and video, interactive leisure software, music, the performing arts, publishing, software and computer services, television and radio.

Meski perbahasan terhadap makna industri kreatif masih hangat, terutama dalam menemukan bentuk dan kandungan yang lebih jelas sama ada sebagai suatu perusahaan seni kreatif seperti lukisan, kesusasteraan, persembahan pentas; atau seni budaya yang terbit dari perayaanperayaan adat tradisi dan warisan, sejarah dan sistem penghidupan seperti permainan, tarian-tarian, persembahan tradisi misalnya Dikir Barat, Nazam, Mak Yong, Wau, yang lazimnya menjadi khazanah peradaban sebagaimana yang diperagakan di arkib-arkib, galeri-galeri dan muzium, atau yang mencakupi pencapaian yang lebih besar seperti arkitektur, arca, muzik dan juga tekstil dan perkakasan rumah. Namun dalam memudahkan pemahaman terhadap lingkaran pengaruh industri kreatif, adalah merujuk pada sebarang amalan dan produksi hasil mahsul kreativiti sama ada 
bersifat persembahan, atau kebudayaan, atau produk-produk material sehinggalah teknologi dengan fungsi kreativiti, estetika dan seni serta budaya menjadi sumber nilai dan pengaruh yang mencipta pasaran (Cunningham 2001: 19; Pratt 2001: 63; Howkins 2002: 7; Martin 2004; Bilton \& Leary 2004: 50).

Perkembangan perusahaan budaya di seluruh dunia, dari zaman kuno sehingga zaman moden adalah ditandai oleh industri seni dan budaya (Myerscough 1988; Caust 2003) yang sehingga sekarang diterima seperti arkitektur, arca, lukisan, muzik, persembahan pentas contohnya teater, Wayang Kulit, Mak Yong, Opera, Bangsawan, tarian; termasuk produk-produk tekstil seperti Batik, Songket, Songkok, 'Petit', sarong, termasuk pakaian misalnya Baju Melayu, Baju Kurung; dan perhiasan-perhiasan misalnya tikar, permaidani, pinggan mangkuk, meja dan almari, pemegang kunci pintu dan cermin rias. Ini termasuk perlakuan-perlakuan moden yang muncul dari perilaku diterima oleh semua seperti 'makanan segera' dan 'minuman berkarbonat' seperti CocaCola; dan juga tabiat sosial contohnya 'Restoran Mamak' dan budaya 24 jam makan dan minum. Tentulah yang muncul sebagai komposisi budaya pada asalnya iaitu perhiasan diri seperti cincin, gelang, rantai, anting-anting, 'cufflink' menjadi perniagaan kreatif paling besar lingkaran pasarannya. Dengan kata lain sesuatu yang telah akhirnya menjadi budaya, yang menunjukkan ciri, sikap, dan kandungan perilaku penghidupan pada peradaban setiap bangsa.

"Culture is thus recast from a distinct sphere of social life to something that permeates everything, from the design of urban spaces, offices, means of transport and communica-tion.... to the promotional strategies of corporations and increasingly governments".

(Flew 2002: 2)

Sedangkan industri kreatif adalah sebuah proses memakai budaya tersebut untuk menghasilkan produk-produk yang lebih representatif dengan melibatkan peranan seni sebagaimana di awalnya, dengan sains dan teknologi dalam masa kini dan future machine seperti gesture recognition di masa depan melalui medium-medium media yang terusan berkembang, iaitu televisyen, filem, internet, serta gajet-gajet media informasi dan digitalisasi yang dapat memasarkan secara lebih meluas, konstruktif dan partisipatif. Industri kreatif adalah ekonomi kreatif itu sendiri, segala proses yang berhubungan dengan kreativiti sebagai sumber utama dalam perusahaan menghasilkan produk-produk dari sastera sehingga multimedia, dan pembangunan arkitektur, transportasi, komunikasi seperti periklanan, kempen-kempen pengedaran dan pemameran; termasuk perniagaan galeri, muzium dan taman-taman rekreasi. Kuasa kreativiti ke atas bentuk dan kandungan akan menjadikan setiap urusan ekoposial memerlukan ketertiban, kecantikan dan kesempurnaan kreatif.

Anekdot yang dapat difahami, seumpama dari 'sebiji kopi' yang dalam industri budaya akan mencetuskan pasaran perniagaan 'minuman berkopi' seperti mélange di Austria, kopi putih di Malaysia, cappuccino di Itali, dan tumbuhlah industri kafe, restoran dan warong-warong di seluruh dunia; sehingga misalnya pasaran kopi yang dikaut untung oleh Tchibo, sebuah perusahaan berasaskan kopi di German adalah sekitar 50-100 juta Euro setahun. Tchibo kemudiannya 
merekayasa industri kopi dengan mengembangkan perniagaan secara 'retail shop' yang mengedarkan pelbagai barangan seperti pakaian, perkakasan rumah, perhiasan dan juga pelancongan (http://www.tchibo.com). Tentulah dari 'sebiji kopi' tersebut secara kreatifnya kemudian akan menumbuhkan industri pembuatan barangan perhiasan berimejkan kopi; perusahaan tekstil dengan situasi kreativiti terhadap imej dan warna kopi; pembuatan iklan dari ilham-ilham berasaskan struktur visual, warna, pola rupa, dan imej kopi; dan tentunya penghasilkan produksi animasi, filem-filem pendek dan video muzik, serta video iklan yang berasaskan kopi yang menandakan munculnya industri kreatif tersebut selepas industri budaya kopi sebagai 'minuman' telah menjadi 'kopi sebagai barangan kemas', animasi dan pakaian. Setidaknya demikianlah kita diberitahu bagaimana suatu proses kreatif akan menterjemahkan perusahaan representasi secara kosntruktif dan akan memajukan aktiviti-aktiviti ekonomi lingkaran di peringkat industri kecil seperti kraftangan/kerajinan, malah sehingga industri internasional seperti periklanan, pakaian/fesyen, media seperti animasi dan filem.

Lalu bayangkan bagaimana transformasi budaya seperti Wau Bulan, Mak Yong, Wayang Kulit, Baju Melayu, Songket, Perahu, Rumah-rumah Melayu, ukiran, keris, hatta alam sekitar di Malaysia seperti Tok Bali di Kelantan dijadikan sumber reflektivitas kreativiti yang mencipta produk-produk di masa depan. Ertinya, sikap menangani budaya dan sumber yang selama ini begitu daif dengan hanya bersandarkan pada keunikan dan amalan penggunaan telah menjadi suatu perusahaan produksi pelbagai sektor upaya ekonomi, dari makanan dan minuman sehingga sebagai perhiasan, sekira diuruskan dengan rasional dan terperinci barangkali akan mencetuskan fenomena kultural.

"Students need to believe that creativity is determined by motivation and effort to a significant degree. They need to understand that creative products are seldom produced without intent and effort, that there is considerable evidence to support the belief that most people have potential they never realize and that persistent effort to develop that potential is likely to be successful.... Students need to know too that... truly outstanding creative works in science and art have often taken many years - sometimes the better part of a lifetime - to produce... They need to understand that if one really wants to be creative in a substantive way, one must be prepared to work at it,"

(Nickerson 1998: 416).

Akhirnya suatu produk budaya yang difahamkan selama ini, ia lebih terpelihara sebagai mahsul elitis dan eksklusif, walhal pula kreativiti lebih demokratik dan inklusif. Sebab itulah setiap perbincangan terhadap makna, bentuk dan kandungan industri kreatif tidak dapat tidak akan mengungkapkan perihal lima rukun kebijakan, yakni; kebijakan kreativiti, harta intelektual, makna-makna simbolik, nilai dan pengaruh gunaan dan kaedah-kaedah produksi. Kreativiti sebagai manifestasi pengetahuan dan kemahiran fikiran terhadap nilai abadi.

Teresa Amabile, sarjana Psikologi dan Ketua Entrepreneurial Management Unitdi Harvard Business School menggarisbawahi makna dan bentuk kreativiti: 
(1) Knowledge: All the relevant understanding an individual brings to bear on a creative effort.

(2) Creative Thinking: Relates to how people approach problems and depends on personality and thinking/working style.

(3) Motivation: Motivation is generally accepted as key to creative production, and the most important motivators are intrinsic passion and interest in the work itself.

Kreativiti sebagai suatu struktur terpenting dalam industri kreatif dapat dibentuk melalui pemajuan kepakaran/expertise dengan pengetahuan teknikal, prosedural dan intelektual. Kemudian kemahiran dan kebakatan dari pengetahuan ini diperkukuhkan melalui cetusan motivasi intrinsik yang lebih efektif berbanding ekstrinsik sehingga potensi-potensi inovasi dapat ditemukan apabila kewibawaan pemikiran kreatif telah berupaya dikembangkan khususnya dalam memahami bagaimana material, objek-objek, simbol-simbol, perilaku, nilai dan sistem hidup, warisan dan budaya dapat diproduksikan untuk menghasilkan produk-produk kreatif mengikut bidang yang boleh menguasai pasaran; the state of the art of the creative content. Carmen Marcus dalam artikelnya "Future of Creative Industries: Implications for Research Policy" menyatakan terdapat pelbagai tafsiran industri kreatif, yang setiap satunya menghuraikan aktiviti-aktiviti heterogenus yang luas dengan bermacam peringkat industrialisasi dan komoditisasi, barangkali jaraknya seumpama dari arca sehingga periklanan, tentang perusahaan seni sehingga pasaran fesyen dan perhiasan. European Commission's DG RTD kemudiannya mendefinisikan ekonomi kreatif atau sektor kandungan industri kreatif sebagai "creation and distribution of goods with an intrinsic cultural, aesthetic or entertainment value which appears linked to their novelty and/or uniqueness" (IPTS EC 2007: 12). Ini disokong oleh sarjana ekonomi Amerika Richard Florida dalam bukunya The Rise of the Creative Class... and How It's Transforming Work, Leisure, Community \& Everyday Life (2002) mengelaborasikan bahawa "human creativity is a virtually limitless resource... creativity also requires a social and economic environtment that can nurture its many forms". Pandangan ini selari dengan perbincangan oleh Friedrich List, ekonomiwan German kurun kesembilan belas yang percaya bahawa kekayaan tekstur budaya adalah basis dalam membangunkan kuasa produktif bangsa bagi gemilang dalam ekonomi. Antisipasi konsep moden yakni human capital, List menyatakan "the mental capital of a nation", menjenterakan bukan sahaja mereka yang membangunkan nilai dengan pertukaran-pertukaran kebolehan, tetapi juga "the instructors of youths and of adults, virtuosos, musicians, physicians, judges, and administrators" (1966: 145). Idea List telah mengubah prediksi ekonomi dunia.

...every individual ...neither intends to promote the public interest, nor knows how much he is promoting it... he is in this, as in many other cases, led by an invisible hand to promote an end which was no part of his intention. Not is it always the worse for the society that it was not part of it. By pursuing his own interest he frequently promotes that of the society more effectually than when he really intends to promote it.

(Adam Smith: 423) 
Institut Nomura Jepun mengklasifikasikan pembangunan ekonomi berlaku di dalam empat era utama iaitu; (1) Industrial, (2) Agrikultural/Pertanian, (3) Informasional, dan sekarang melalui semua bentuk evolusi teknologi, dan (4) Kreatif, atau inovasi yang berterusan. Pink (2005) turut membangunkan idea ini dalam tulisannya $A$ Whole New Mind yang menggarisbawahi bahawa pembangunan ekoposial sejagat dapat dikategorikan sebagai (1) Era Agrikultur (petani), (2) Era Industrial (pekerja kilang), (3) Era Informasi (pekerja berpengetahuan), dan (4) Era Konseptual (pereka dan pencipta). Berdasarkan ehwal tersebut, setiap satu era hendaknya menjadi inspirasi buat era akan datang. Era kreativiti yang berkembang di masakini adalah terinspirasi dari dan berasas pada era industri dan informasi yang telah membangun sebelumnya, atau dalam maksud yang lain, kreativiti hendalah difahamkan dan dibangunkan dari asas-asas dan kaedah-kaedah industrial dan informasional. Kreativiti dalam pengaruh proses industrial adalah berhubungan secara rapat dengan inovasi. Baden (1994: 27) mendeskripsikan kreativiti, yakni struktur terpenting dalam ekonomi kreatif atau industri kreatif melalui teori yang dinamakan Conceptual Space yang mempunyai 3 makna utama;

1) Creativity is a matter of mapping and exploring structured conceptual spaces that have various dimensions, limits, pathways, and levels, 2) Sometimes creative ideas emerge through in-depth exploration of an existing conceptual space, 3) Deeply creative ideas transform and sometimes profoundly alter conceptual spaces.

Baden juga mengkategorikan kreativiti sebagai modal kebijakan ekonomi kreatif masa depan dalam dua bentuk ketegori, (1) Kreativiti Psikologikal, iaitu rekacipta novel idea yang seseorang itu belum pernah ada sebelum ini, (meski kemungkinan ada orang lain turut terfikir sama); (2) Kreativiti Historikal, iaitu idea-idea kreatif personal yang belum pernah dicetuskan, dihasilkan atau difikirkan oleh orang lain sebelum ini. Manakala March (1999: 126) mendefinisikan kreativiti sebagai proses-proses yang berhubungan dengan exploration \& exploitation, sama ada eksplorasi/penerokaan melibatkan pencarian, peninjauan, pengukuhan dan penghasilan idea-idea dan inovasi-inovasi; dan eksploitasi/rekayasa yang melibatkan aktiviti pembaikan, pemakaian, dan penggunaan pengetahuan, dan pembentukan rutin-rutin atau perilaku semasa. Hakkarainen (2008: 72) pula memaknakan kreativiti pada 3 pendekatan, iaitu (1) asumsi kreativiti adalah "to bring something into being or form out of nothing", (2) idea kreatif mungkin dapat diterima sebagai suatu "novel combination of old ideas", dan (3) kreativiti sebagai bahagian dari bagaimana fundamentalnya idea-idea baru dibangkitkan. Franklin (2003: 103) memperjelaskan secara lebih mudah bagaimana sistem dan kandungan kreatif itu terbentuk, dan seterusnya menderu pada pembangunan kreativiti dan penghidupan darinya iaitu ekonomi, yakni kreativiti adalah "as problem identification and idea generation whilst innovation defined as idea selection, development and commercialization". Mengikut Bishop (2004: 18) juga karakteristikkarakteristik yang terlibat dalam acuan kreativiti ialah "curiosity, vocabulary, good visual, imagery, tolerence to ambiguity, risk taking".

Pandangan ini sama dengan apa yang disebut sebagai "Theory U” oleh Scharmer (2008: 212) yang perilaku dan pengetahuan kreativiti adalah terhasil dari proses yang panjang dengan pelbagai peranan, pengaruh, tatacara dan saingan yang berhubungan dengan "Three-Open Setting: OpenMind, Open-Heart, Open-Will'. Kreativiti sebagai suatu industri adalah gabungan pengalaman dan pengetahuan menguruskan sumber-sumber alamiah dan budaya bagi menghasilkan lingkaran 
produk-produk perkhidmatan dan perkakasan yang mencetuskan manfaat bagi penghidupan yang aman, indah dan sejahtera.

\subsection{Bentuk Dan Kandungan}

"The creative cities were nearly all cosmopolitan; they drew talent from the four corners of their worlds, and from the very start those worlds were often surprisingly far-flung. Probably, no city has ever been creative without continued renewal of the creative bloodstream".

(Hall 1998: 285)

Pada dekad-dekad akan datang dunia akan bergerak secara lebih pantas dan terbuka. Bagi Malaysia, sebagaimana juga dengan negara-negara lain di seluruh dunia; rapidnya perana dan pengaruh teknologi-teknologi baru terutama saitek media dan peningkatan perilaku serta kesan globalisasi bermaksud suatu lonjakan yang begitu melaju dari manufakturik tradisional kepada

perkhidmatan-perkhidmatan dan inovasi, atau penghasilan kreativiti. Ekonomi fabrikal/perkilangan akan diambil alih oleh komuniti-komuniti kreatif secara progresif dengan 'raw material' adalah kebolehan-kebolehan mereka dalam rekayasa, rekacipta dan rekabina. Menghadirnya ekonomi digital baru, nilai-nilai tunamaterial berkembang membentuk nilai material, dengan pengguna semakin ghairah mencari-cari dan memperolehi pengalamanpengalaman baru nan lebih menakjubkan. Sekali gus ini akan menderu keinginan dan kebolehan merekacipta pengalaman-pengalaman sosial lalu jaringan adalah faktor paling berpengaruh dalam menguasai persaingan di masakini.

Sekira Malaysia mahu kekal kompetitif dalam persekitaran dunia yang semakin berubah, maka sangat-sangat perlu malah begitu penting untuk menempatkan kreativiti dan inovasi dalam kondisi-kondisi yang betul dan tepat bagi mengadiluhung diri dalam budaya entreprenurial baru. Menafikan posisi ini, akan memusnahkan potensi untuk berserta dengan masa depan.

Terlalu banyak dan meluas potensi-potensi yang ada pada Malaysia dalam industri kultural dan kreatif bagi membangunkan lingkaran pasaran kerjaya, dan meninggikan pendapatan terutama dalam keinginan untuk menempatkan diri sebagai negara berpendapatan tinggi. Bagi mencapai dan melengkapkan hasrat itu maka tentulah Malaysia harus merencanakan proses-proses ke arah membawa potensi kultural dan kreatif yang ada, dari sumber-sumber masalalu menjadi hasil masa depan, misalnya material-material kreatif dalam budaya tradisional pada produk-produk baru yang dapat mengisi pasaran yang tercetus akibat perkembangan saitek media baru, industri pelancongan, perhotelan, dan pasaran kreatif-inovatif. Melengah-lengahkan projek memajukan kreativiti maka akan menggagalkan kuasa terhadap ekonomi masa depan. Tentulah cabaran ini bukan sahaja suatu proses memaknakan ekoposial baru, dan tentulah bukan seperti pemikiran meniadakan subsidisubsidi atau bantuan kerajaan yang kemudian mencetuskan kegelisahan dan kemarahan rakyat; atau, menubuhkan dan mewujudkan kolej-kolej, universiti-universiti dan mengubah sistem pendidikan dari bersikap teoritikal kepada praktikal dan kemahiran; sebaliknya hendaklah menjadi suatu projek membentuk kepercayaan buat setiap ahli masyarakat yang bakat, minat, kepandaian, kemahiran, pemikiran dan pengetahuan mereka terhadap persekitaran, sama ada tentang budaya 
maupun teknologi boleh menjadi material bagi sebuah perusahaan kreatif yang menguntungkan. Untuk mencapai kepercayaan ini, Malaysia hendaklah mengidentifikasikan dan berbuat pelaburan dalam sumber-sumber baru kebijakan, keteguhan dan pemacu-pemacu perkembangan yang inklusif yang mampu mengambil alih baton ekonomi masa depan.Ini kerana kemakmuran masa depan negara ini adalah bergantung pada bagaimana kita menggunakan sumberdaya-sumberdaya, pengetahuan dan bakat-bakat kreatif dalam mengeksplorasikan inovasi. Membangunkan segala sumberdaya yang ada, dari budaya warisan, alam sekeliling, adat resam dan seni seperti permainan Wau Bulan, minuman Teh Tarik, makanan Roti Canai dan Nasi Lemak, perkakasan dan perhiasan dari timah, perak, tembaga dan emas, tekstil Batik dan Songket, termasuk persembahanpersembahan misalnya Nazam, Dikir Barat, Ghazal, Tarian-tarian dan alatan muzik contohnya Rebana Ubi dan Kompang sehingga pengetahuan kreatif moden yang pelbagai, malah kelebihan sebagai negara majmuk dengan beragam-ragam seni budaya dan cara hidup; dalam kata yang lain, membangunkan akan budaya-budaya kita yang begitu kaya dan kepelbagaian, Malaysia hendaknya menjadi pencetus pada cara-cara baru dalam merekacipta nilai-nilai masadepan, dengan mampu untuk hidup bersama, berkongsi sumberdaya dan merayakan kemajmukan ini.

\section{"Managing creativity involves knowing, first, when to exploit the non-rivalrous nature of ideas and, second, when to assert intellectual property rights and make one's ideas- as-products rivalrous. These two decision points are the crux of the management process".}

(Howkins 2004: 32)

Industri kreatif nyata telah berkembang dengan begitu pantas dan rancak sejak beberapa abad, sebelum kesatriaan saitek maklumat khususnya internet dan media digital serta perusahaan parisiwisata/pelancongan mengambil alih fabrik-fabrik kejuruteraan berat dan lain-lain industri utama seperti petrolium, perlombongan, dan persenjataan, dan terus-terusan mencetuskan kebangkitan ekoposial baru di sepanjang dua dekad masa lalu. Seratus tahun dahulu, yakni mengadiluhungnya Kurun 21, tidak lebih daripada $10 \%$ tenaga kerja telah bekerja di dalam sektor ekonomi kreatif seperti perusahaan dan perniagaan kraf, tekstil, seni persembahan, perhiasan dan perkakasan rumah, fesyen dan perhiasan diri dan seumpamanya. Kurang daripada 15\% tenaga kerja terlibat sepenuhnya dalam aktiviti-aktiviti kreatif ini pada tahun 1950. Tetapi di sepanjang dua dekad yang lalu, kreativiti telah pun menjadi pemacu utama dalam pembinaan dan pengukuhan ekonomi dunia sekali gus membawa ledakan industri kreatif kemudiannya. Masakini, di antara 25\% malah lebih 30\% (Markusen dan Schrock 2006, Power 2002), dan menjelang 2020 akan mencecah hampir 45\% tenaga kerja dan kerjaya dalam ekonomi industri nasional di seluruh dunia akan terlibat dalam sektor ekonomi kreatif (Wyszomirski, 2002: 73-79), yakni terlibat dalam sains dan kejuruteraan, penyelidikan dan pembangunan, industri berasaskan teknologi dalam industri seni, musik, budaya, estetika dan rekabentuk, atau dalam kerjaya-kerjaya berasaskan pengetahuan seperti penjagaan kesihatan, pengurusan kewangan dan undang-undang. Malah, dalam dua dekad terakhir sebelum ini dunia sudahpun mengalami perubahan-perubahan struktural ekoposial. Pertukaran dari lingkaran Marx, dari agrikultural kepada sistem industrial kapitalis, yang mensubstitusikan satu set tentang input-input fizikal (tanah dan buruh manusia) atau pada yang lain (material-material tulen dan buruh fizikal), dan sekarang diikuti oleh suatu jenis transformasi baru, yang mana secara fundamentalnya adalah berasaskan kecerdikan manusia, pengetahuan dan 
kreativiti. Ini ditegaskan oleh Wyszomirski (2002: 75) yang kajian terkini menunjukkan lonjakan industri kreatif begitu pantas dan kuat menjelang suku kedua Kurun 21 dan semacam akan menguasai seluruh proses kepercayaan ekoposial Kurun 21 ini yang ditunjukkan oleh kebangkitan minat dan pengaruh serta pembangunan ekonomi kreatif, yang menyebabkan hampir keseluruhan dunia mula mengalihkan sasaran pembangunan kepada kreativiti dan inovasi. Sikap ini dilajukan lagi dengan kebangkitan mediasfera melalui potensi media sosial atau sosialsfera.

"The focus on creative industries in national or regional competitive strategies has been attributed to the demise of a Fordist mode of production, which was centered on cost imperatives and secured through a national, Keynesian regulatory regime. With integrated international markets and the advent of new technologies, there has been a search for new sources of competitive advantage. And the critical ground for new forms of competition has been an economy in which creativity and innovation play a prominent role".

(Lash and Urry, 1994)

'HARRY PORTER' adalah suatu contoh terbaik dalam memahami bagaimana lingkaran bentuk dan kandungan industri kreatif terjadi; bermula dengan rangkaian industri-industri produksi, ke industri-industri perkhidmatan dan kesenian, dan kraftangan atau kerajinan: idea dari sebuah rekayasa imaginasi akhirnya menjadi buku, filem, video mainan, permainan dan hiburan kanak-kanak, fesyen seperti t-shirt, alat-alat riadah dan rekreasi serta hiburan, taman-taman wisata/pelancongan, biskut dan coklat, dan sebagainya. Proses kreatif adalah suatu adikudrat dan graviti kemahiran yang sangat tinggi dan bersepadu. Setidak-tidaknya dua sikap praktikal dinamik yang terlibat - proses kreatif, dan proses produksi serta distribusi sebagai matlamat akhir penghasilan produk; dan upadaya artistik, yang mana sisi pertama dari dua sikap praktikal dinamik tersebut adalah tersangat memerlukan kesungguhan individualistik yang tinggi dan nan kedua, nilai pasaran. Meski nilai pasaran sangat terhad untuk diprediksikan terutama dalam proses mengenalpasti keinginan massa atau alam pengguna untuk sealiran dengan dinamisme idea pencipta, namun adakala kepercayaan itu dibentuk oleh kebolehan menghasilkan produk yang luarbiasa dan mencipta nilai dan budaya yang tinggi. Ini seperti untuk meneka adakah kumpulan band remaja 'Bunkface' akan dapat menyaingi 'The Beatles', atau bilik tidur remaja di Sheffield semacam grup band The Arctic Monkeys, atau kafe di Ediburgh semacam Harry Porter oleh J K Rowlings, atau juga sebuah laptop milik seorang graduan lulusan Harvard semacam Mark Zuckerberg yang mencetuskan gelombang fenomena Facebook? Semua ini memerlukan sebuah kebersekutuan antara sikap individual dalam menguruskan sumber-sumber potensi yang ada padanya dengan sumber-sumber material yang terdapat di sekelilingnya.

"The Creative Industries is the fastest growing sector of the UK economy growing at an average of $6 \%$ per annum and $10 \%$ globally. It contributes $7.9 \%$ towards UKGDP and almost 2 million people are employed within its 13 sub-sectors. It is a dynamic and innovative sector, characterized by a preponderance of small and microenterprises that rely heavily upon a constant influx of entrepreneurial, creative and flexible individuals. Rapid transformation in recent years caused by the impact of new technologies, particularly digital media, has altered the relationships between 
industry sub-sectors as well as breaking down the boundaries between creative producer and creative consumer. The Creative Industries coupled with the cultural sector also has a wider social significance and impacts on individuals, communities and society in ways that cannot be measured in simply economic terms. The sector is one of the most highly educated with around 43\% having degrees or higher level qualifications, significantly more in some sub-sectors, compared with $16 \%$ of the workforce as a whole. We also know that graduates from creative arts, design and media courses are more entrepreneurial than their peers with around one third of all self-employed first degree graduates coming from these disciplines. Despite this, the current shortage of meaningful opportunities for entrepreneurial learning within HE and FE means that the majority leave education unprepared for the realities of forging a career in the sector. ("Developing Entrepreneurship in the Creative Industries: Making the Case for Public Investment":

(DCMS July 2006)

Maksudnya, hanya dengan pengetahuan dan sikap kreatif yang ada pada setiap orang itu, sekira dibentuk dengan potensi-potensi inovatif yang pragmatik maka seseorang itu akan dapat mengetahui masa lalu, menguruskan masa kini, dan membangunkan masa depan.

Tentulah kreativiti dan inovatif tidak boleh dibentuk dari sebuah proses jangka pendek, misalnya dengan menubuhkan pelbagai sekolah teknik dan vokasional, institut kemahiran, dan universiti; namun asasnya membina pengetahuan adalah sebuah gerakan terpenting terutama dalam membangunkan keupayaan 'mengetahui apa' dan 'mengetahui bagaimana' atas sesuatu perkara.

Tanggapan yang sekian banyak kreativiti warisan telah dan akan musnah, dan pandangan ini bukannya suatu tohmahan yang diada-adakan bagi menyalahkan pelbagai perilaku dan sistem ekoposial yang punah akibat perlawanan kepentingan-kepentingan politik misalnya, atau pertembungan nilai-nilai sebagaimana yang dialami oleh Dikir Laba, Gasing, Muzik Kertok, Muzik Beduk, Arkitektur Buah Betong, Tarian Inai, malah sekira tidak berjaya diuruskan dengan baik, mungkin juga Wau Bulan, Pertukangan Perak di Kelantan, Mak Yong, Main Puteri dan lainlain akan menghembuskan nafasnya yang terakhir. Tentulah anggapan ini akan dapat dipositifkan sebaik kemampuan untuk mengelola kebangkitan industri teknologi maklumat, pelancongan dan perhiasan benar-benar menemukan bentuk dan kandungannya yang selari dengan Kurun 21 dan kurun-kurun masa depan. Gravitas inovasi ini dengan sendirinya akan membangunkan industri kreatif di Malaysia, dan tentulah sumber-sumber inovasi yang bertebaran dalam budaya hidup kita akan mempercepatkan pencapaian untuk muncul sebagai laboritorium ekonomi kreatif yang tidak kurang besarnya pengaruh di dalam kebersamaan pesatnya ekonomi kreatif dunia. Chris Smith, mantan Setiausaha Budaya, Media dan Sukan Britain sewaktu Persidangan Industri Kreatif Eropah, bertempat di Vilnius, Lithuania pada 2003 menjelaskan:

I believe [...] that we are living through a new economic revolution in the advanced economies of Europe. We have moved [...] over the centuries, from an agricultural economy to an industrial manufacturing economy to a service economy. And now I 
believe that we are beginning to move from a pure service economy to an economy that is based very substantially on creativity. And that is not just true of the economies such as the United Kingdom which have for many years had the advantage of the free market entrepreneur system. I think it is also true of economies in developing countries.

Mengikut Tepper (2002: 159), kebanyakan pembuat dasar/kebijakan di seluruh dunia mula berpercaya yang telah berlakunya begitu banyak perubahan dinamik dalam lingkaran bentuk dan kandungan ekonomi terutama menguatnya pengaruh-pengaruh posisi seni dan budaya dalam masyarakat. Perubahan ini termasuk globalization, digitalization, the rise of the 'knowledge' worker, the boom in intellectual property, changes in leisure consumption, malah Tepper juga menegaskan yang seni dan budaya di masa kini benar-benar telah menjadi jentera pembangunan dan perkembangan ekonomi, dengan para sarjana mula sibuk berbahas berkenaan kota kreatif, kluster kreatif, dan ekonomi kreatif, dan kebangkitan generasi kelas kreatif. Di masa kini, bila mana setiap pemikir, politikawan dan ekonomiwan mula bercakap tentang luar biasanya peranan, pengaruh dan energi yang ada pada kreativiti sebagai pemacu ekonomi di masadepan, 30 tahun yang lalu dalam bukunya Coming on Postindustrial Society (1973), Daniel Bell telah memperjelaskan mayatiliknya terhadap kemunculan, kebangkitan dan kekuatan masyarakat yang ekonomi mereka dimagnetiskan oleh pengetahuan teoritikal. Bell juga melihat kebangkitan "knowledge class" yakni para penyelidik, perekacipta dan jurutera-jurutera, dan berlalu dari industri pembuatan ke perkhidmatan.

Maka, Malaysia hendaklah dengan sedaya pantas yang boleh bergerak dari kebergantungan terhadap industri pembuatan, pembinaan dan perkilangan kepada ekonomi berteraskan pengetahuan dengan memperkasakan praktis-praktis kreatif dan artistik, melalui pengukuhan struktur pendidikan dan kewangan sebagai pemacu dalam menjentrakan keseluruhan sumberdaya yang diperlukan dalam ekonomi kreatif ini. Sebagai prakarsa awal, selain dari mengenalpasti sumberdaya-sumberdaya seperti budaya, seni dan bakat, faktor-faktor pembentukan magnetisme ekonomi kreatif juga perlu diberi perhatian penting, yakini dengan mengukuhkan imperatif modal teknologi iaitu menemukan cara untuk memaksimumkan produksi melalui inovasi; imperatif modal insan iaitu memaksimumkan kebolehan, kemahiran dan kebakatan serta pengetahuan dan ini akan mengurangkan kebergantungan pada tenaga buruh fizikal yang adakalanya mencetuskan pelbagai krisis ekoposial terutama dengan kebanjiran pendatang-pendatang haram dari pelbagai pelusuk sempadan dunia kesan dari keperluan industri manufaktur; dan imperatif modal pasaran, iaitu untuk menstimulasikan dan memcipta identiti-identiti pengguna baru, keperluan dan keinginan baru, dan kepuasan-kepuasan semasa dan masa depan.

Two U.S. counties -New York and Los Angeles - have become image-producing, critical forces that provide high visibility and a global reach for American cultural values. By clustering arts, entertainment, and cultural organizations, these two regions have developed into major strategic sites that consolidate vast concentrations of creative resources. The result is an infrastructure that has secured for them - and, by extension, the United States-a dominant place on the global cultural scene. These arts, entertainment, and cultural organizations form the core of three sectors whose inter- relationships with each other magnify their impacts. Awareness of these 
synergies has led many to associate New York and Los Angeles "with a distinctive aura and mystique in the form of certain impressions, personae, memories, styles, [and] trends

(Scott 1996: 306-23).

BOP Consulting yang berpusat di United Kingdom, di dalam makalah persidangan Creative Industries Understanding and Approaches to Mapping: Sao Paulo, pada November 2009 menjelaskan ekonomi kreatif adalah dipacu oleh kreativiti, kultur dan inovasi. Ini melibatkan 6 Kompleks Industri, iaitu:

1. Industri Kreatif

2. Industri Hiburan

3. Industri Hakcipta

4. Industri Kultural

5. Industri Kandungan

6. Industri Riadah

Richard Florida dalam bukunya The Rise of the Creative Class menjelaskan pembangunan ekonomi baru atau ekonomi kreatif yang dijayakan oleh mereka yang kreatif, adalah dipacu oleh "three T's: Teknologi, Talent and Tolerence" (Florida 2002: 249). International Forum on Creative Industries (Salvador, Brazil; April 2005) dan UNCTAD High-Level Panel on Creative Industries and Development (Sao Paulo, Brazil; June 2004) menstrukturkan bentuk dan kandungan industri kreatif dalam beberapa sub-sektor:

The recording industry; music; performing arts; film and video; publishing; software and computer services; photography; art and antiquities market; radio, television and cable broadcasting industries; advertising; crafts; architecture; design; designer fashion; interactive leisure software; cultural heritage (tangible and intangible); tourism.

Ini disokong dari kenyataan oleh Dr Vanus James, Profesor Pelawat dan Penyelidik Kanan di Fakulti Ekonomi, Universiti Teknologi Jamaica sewaktu membentangkan hasil penemuan penyelidikan beliau terhadap Industri Kreatif Jamaica, di mesyuarat Industri Kreatif Jamaica, anjuran Jamaica Intellectual Property Office (JIPO) dan EXIM Bank pada 17 November 1009; "A dollar of foreign exchange put into music and other recreation forms yields \$6.18, [while] that same dollar put into communications yields [only] \$1.49". Berdasarkan rangkuman beberapa pandangan terhadap bentuk dan kandungan industri kreatif, dari aspek makna dan struktur industri termasuk lingkaran pasarannya, di peringkat suarjagat; maka UNESCO seperti lazimnya memberi penegasan terhadap aspek-aspek kultural, iaitu emfasis dari produksi dan distribusi intangible cultural content. Manakala, World Intellectual Property Organization (WIPO) juga tidak mengejutkan untuk menegaskan sektor kreatif adalah dibangunkan dari lingkaran industri-industri hakcipta/copyright. Dan The United Nations Conference on Trade and Development (UNCTAD), melihat sebaliknya, iaitu bagaimana perdagangan boleh menjadi pemacu ekonomi kreatif, dengan 
rujukan partikular terhadap potensi-potensi pembangunan sektor-sektor kreatif di negara membangun (UNCTAD 2008).

Sayugia itu, dalam situasi kepelbagaian tafsiran, pemahaman, kepercayaan dan pengetahuan terhadap makna, bentuk dan kandungan industri kreatif, namun sikap terhadap ekonomi kreatif adalah hampir sama iaitu tentang bagaimana graviti kreatif dimajukan dalam industri budaya. Maksudnya industri kreatif itu adalah semua yang terlibat dalam produksi dan distribusi produk barangan atau perkhidmatan seni-seni kreatif, warisan budaya,; semua media audiovisual (filem, musik, televisyen, radio, video, permainan komputer, permainan digital, gajet-gajet komunikasi), media cetak dan penerbitan termasuk jaringan psarannya seperti pembuatan instumen-instrumen muzik, penjualan buku termasuk naskah-naskah antik, pengedar seni komersial. Tentunya dengan kebangkitan saitek media maklumat dengan internet sebagai pemacu, termasuk kepesatan industri telekomunikasi digital dengan segala bentuk gajet-gajet seperti telefon pintar (smartphone), contohnya bentuk-bentuk media sosial seperti iPhone, iPad, dan lain-lain menempatkan pula elemen periklanan, fesyen dan rekabentuk, arkitektur dan juga lukisan. Oleh kerana distribusi turut melibatkan hubungan antara seni, warisan dan massa sebagai pengguna maka industri-industri riadah dan pelancongan turut berada sebagai kandungan kreatif, yang pula melibatkan muzium, arkib-arkib, galeri-galeri, seni persembahan seperti opera dan teater, orkestra, sukan, taman-taman rekreasi dan juga adat-adat tradisi seperti bahasa, kraftangan, pustaka-pustaka sejarah contohnya bahan-bahan antik dan artifak, perhiasan dan perkakasan rumah, dan seni kulinari.

Lalu persoalan terhadap apakah bentuk dan kandungan industri kreatif yang boleh difahami, tentulah dalam suatu proses ekonomi yang begitu sedang berkembang perselisihan terminologi ini sama sekali tidak perlu. Ini kerana industri kreatif adalah telah diterima sebagai suatu industri menguruskan budaya.

City of Vienna (MA 27 EU-Strategy and Economic Development), Filmfonds Wien and the Chamber of Commerce Vienna commissioned a study that aims at investigating the innovation and employment potential within the following disciplines: Music, Architecture, Literature, publishing and print media, Audiovisual field, Fine arts and the art market, Graphic arts, fashion and design, Multimedia, software, games, and the Internet, Performing arts and entertainment, Museums and libraries Advertising

Bagi Department of Culture, Arts and Leisure Northern Ireland, dalam proposal pembangunan industri kreatif yang dibentangkan pada Oktober 2008, lingkaran industri kreatif adalah seperti yang digambarkan dalam diagram ini: 


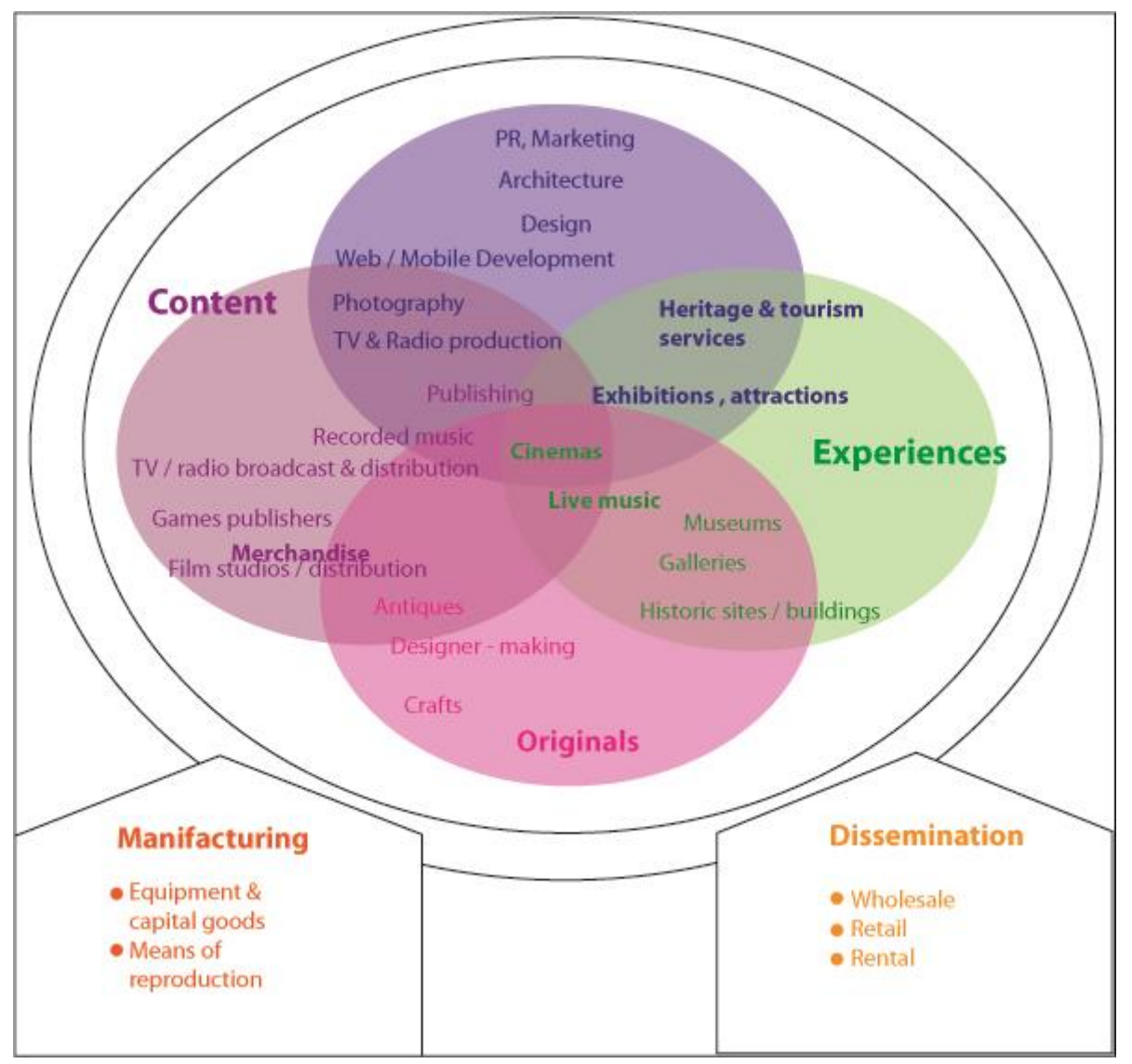

Rajah 1 : Lingkaran Industri Kreatif

Maksudnya bentuk dan kandungan industri kreatif dapat dipecahkan dalam Tiga Sektor Lingkaran iaitu:

1. Sektor Lingkaran Rekabentuk - terdiri dari subsektor seperti arkitektur, kraf, rekaan, fesyen, antikuiti;

2. Sektor Lingkaran Ekspresif - terdiri dari subsektor seperti muzik, persembahan seni, seni visual;

3. Sektor Lingkaran Media dan Informasi - terdiri dari subsektor seperti periklanan, filem, multimedia dan penerbitan mainan, software/aplikasi komputer, televisyen dan radio.

Sektor lingkaran industri kreatif ini pula dibentuk oleh Empat Generik Model Industri Pasaran dalam perekaan, pembikinan dan pemameran produk-produk keratif atau kultural, termasuk pasaran perkhidmatan penggunaan produk-produk kreatif dan kultural, yang boleh diidentifikasikan sebagai berikut:

1. Profesional-profesional Perkhidmatan Kreatif - mereka yang menawarkan perkhidmatan asuhan, bimbingan, latihan dan pendidikan, penyelidikan dan perundingan seperti Perhubungan Awam, Komunikasi Media, Arkitektur dan Perancangan Bandar, Rekabentuk dan Hiasan Dalaman, Penerbitan TV dan Radio, Pembangunan Multimedia, Rekabentuk 
Web dan Mobile, di mana perkhidmatan adalah berasaskan bayaran terhadap masa, kepakaran dan mungkin idea-idea.

2. Produser-produser Kandungan Kreatif - para penerbit, pengurus, pengarah dan pembikin, sutradara, krew/tenaga kerja produk-produk intelektual atau hakcipta, seperti syarikatsyarikat pembikinan filem dan televisyen, permainan komputer dan video, menerbit muzik, atau pengusaha buku dan majalah-majalah.

3. Pembekal-pembekal Pengalaman Kreatif - misalnya pengusaha teater, opera dan tarian, promosiwan yang mengelola pameran-pameran, konsert, acara-acara dan segala aktiviti persembahan.

4. Pengusaha-pengusaha Original Kreatif - mereka yang terlibat dalam menghasilkan dan membangunkan artifak-artifak fizikal yang berharga dan eksklusif, autentik, termasuk tukang-tukang kraf, artis-artis visual, pereka-pereka rekabentuk yang mana nilai atau harga ditentukan oleh keunikan, kecantikan dan keistimewaan produk yang dihasilkan.

In the UK the Creative Industries account for 8\% of GVA and 7.9\% of GDPi (DCMS2001). They produce almost $£ 1$ in $£ 12$ of our total GDP - a higher proportion than in any other country. They contribute $£ 11.4$ billion to our balance of trade, well ahead of the construction industry, insurance and pensions, and twice that of the pharmaceutical sector, and they employalmost two million people (DTI2004). DCMS has identified that it is the fastest growing sector in the UKgrowing at twice the rate of the overall economy.

Comprising 13 distinct sub-sectors, it is a dynamic and innovative sector, characterised by a preponderance of small and micro-enterprises with a small number of large organisations. They typically account for 4-7\% of total employment (20\%if tourism, hospitality and sport are included). Commonly, Creative Industry companies are highly networked, organising work2 around commissioned projects often within complex supply webs.

(DCMS 2006)

Kemarian mendadak dan begitu pantas berkembang industri dan teknologi media baru, telah membentuk masyarakat maklumat (Information Society), malah dengan meletusnya media sosial akhirnya telah membangunkan sosialsfera, yang terkandung di dalamnya semua bentuk hubungan penghidupan iaitu sejarah, budaya, seni dan sains, teknologi, komunikasi dan informasi, perniagaan dan perdagangan, atau secara lengkapnya dapat disebut sebagai meletusnya jaringan ekonomi, politik dan sosial yang tidak terpisah atau disebut di sini sebagai 'ekoposial'. Hal-hal dan ehwal-ehwal masa lalu, menjadi suatu potensi pada masa kini, dan membuka lingkaran potensi-potensi di masa depan. Misalnya, Wayang Kulit yang menjadi salah satu seni hiburan paling menguntungkan dan paling mempengaruhi penghidupan masyarakat di Kelantan di masa lalu, di sepanjang kurun-kurun 15, 16 hingga 19; kemudiannya menjadi suatu seni warisan yang dipelihara dan dijangukasakan sebagai sumber daya sejarah dan budaya di masakini dengan pameran dan persembahan diadakan sama ada di panggung-panggung seni maupun di acara-acara kenamaan dan kebangsaan; dan tentunya Wayang Kulit ini juga boleh menjadi semacam budaya 'kopi' juga, yang mungkin dari idea, bentuk dan kandungan sedia ada pada seni dan karyanya 
boleh menjadi rekacipta-rekacipta kreatif dengan menghasilkan pakaian, barang-barang kemas dan perhiasan berasaskan watak-wataknya seperti Sita Dewi, Seri Rama, Wak Dogol dan lain-lain, malah hingga boleh menjadi naskah animasi dan filem digital yang boleh dipasarkan ke serata dunia. Dengan kata lain, bentuk dan kandungan industri kreatif itu adalah sektor-sektor presentasi dan representasi yang sekira mengikut pandangan Creative Industries Task Force Mapping Documents (CITF 2001) di United Kingdom adalah terdiri dari:

1. Industri Kreatif Analog seperti seni, kraf dan kerajinan, antik, arkitektur, fesyen, rekabentuk;

2. Industri Kreatif Media seperti filem, TV dan radio termasuk muzik, iklan-iklan;

3. Industri Kreatif Digital yang melibatkan saitek internet dan media baru seperti perisian (software), permainan riadah interaktif, permainan video; yakni yang melibatkan aktivitiaktiviti produksi, distribusi, ekshibisi dengan nilai-nilai warisan, budaya tradisi dan moden, estetika, hiburan termasuk sukan, makanan dan juga perhiasan rumah dan bandar.

Tentulah dalam kurun sosialsfera dengan kepercayaan demokrasi partisipasi, atau demokrasi digital ini, budaya akan terinovasi secara kreatif dan akhirnya membentuk industri kreatif. Industri kreatif akan menjadi graviti dalam semua proses ekoposial sejagat.

In microeconomic theory industries do not exist. What exists, of course, are agents, prices, commodities, firms, transactions, markets, organizations, technologies and institutions. These are economically real at the level of any individual agent's transformations or transactions.

(Potts dll 2008: 2)

Cunningham, Banks dan Potts (2008: 2-18) menghuraikan bentuk dan kandungan industri kreatif atau ekonomi kreatif dalam model berikut:

The 'creative economy':

evolving sideways: $\longrightarrow$ (co-present concepts and models of creative industries)

\begin{tabular}{|l|l|l|l|}
\hline $\begin{array}{l}\text { Creative } \\
\text { Form }\end{array}$ & $\begin{array}{l}\text { Art, } \\
\text { Individual }\end{array}$ & $\begin{array}{l}\text { Media, } \\
\text { Industry }\end{array}$ & $\begin{array}{l}\text { Knowledge, Maket/ } \\
\text { Culture }\end{array}$ \\
\hline $\begin{array}{l}\text { Model of } \\
\text { culture }\end{array}$ & Residual & Dominant & Emergent \\
\hline $\begin{array}{l}\text { Economic } \\
\text { model }\end{array}$ & (1) Negative & (2) Neutral & $\begin{array}{l}\text { (3) Positive, } \\
\text { (4) Emmergent }\end{array}$ \\
\hline $\begin{array}{l}\text { Policy } \\
\text { response }\end{array}$ & "Welfare" & "Competition" & $\begin{array}{l}\text { "Growth" } \\
\text { "Innovation" }\end{array}$ \\
\hline
\end{tabular}


Dengan mengambil juga rumusan-rumusan yang dinyatakan oleh Miége (1989: 145-148) misalnya yang menyatakan industri kreatif terbentuk dari 3 Logik iaitu:

1. The Publishing Logic, yakni melibatkan industri pembikinan karya seperti buku, filem, iklan, dan muzik;

2. The Flow Logic, yakni melibatkan industri penghasilan produk pengunaan secara berterusan seperti teater, panggung, radio, televisyen dan media baru;

3. The Written Press Logic, iaitu industri komoditi yang mempunyai pasaran tetap dan berterusan misalnya majalah dan akhbar. Pandangan evolusi budaya (Lotman 1990), sebelum itu lingkaran kuasa budaya (Raymond William 1973) yang mengkategorikan kultural di dalam skema-skema: residual, dominant dan emergent. Semua ini secara keseluruhannya dapat dirukunkan dalam fragmen industri budaya, iaitu:

Pertama; Industri kreatif sebagai seni - asadaya suatu model ekonomi negatif. Di sini kreativiti sebagai domain akan kegagalan pasaran. Seni sentiasa memerlukan bantuan/subsidi dari lain-lain sektor ekonomi. Secara umumnya dasar-dasar bertindakbalas sebagai suatu model tanggungjawab (welfare). Ini berhubungan dengan sisi dinamik budaya 'residual'.

Kedua; Industri kreatif sebagai media dan industri - asadaya suatu model ekonomi neutral. Media dan industri-industri tidak memerlukan dasar-dasar perhatian istimewa selain dari polisi persaingan. Ini berhubungan dengan sisi budaya 'dominant'.

Ketiga; Industri kreatif sebagai pengetahuan (pasaran dan budaya) - asadaya suatu model ekonomi positif atau 'emergent'. Di sini industri-industri kreatif adalah sesuatu yang luarbiasa dan istimewa, ini kerana ianya boleh menjadi suatu nyalaan perkembangan evolusionari hubungan antara (kultural) jaringan sosial dan (ekonomik) enterprise, di mana pasaran memainkan peranan utama dalam mengkoordinasikan adopsi dan retensi kepentingan dan adiluhung pengetahuan. Ini memerlukan polisi-polisi 'pertumbuhan' dan 'inovasi', dan berhubungan dengan budaya 'emergent'.

Dengan kata lain, industri kreatif, bentuk dan kandungannya dapat difahami sebagai bahagian dari mekanisme sistem kreatif. Perspektif sistem-sistem kreatif yang kemudian berakar dari perspektif sistem-sistem inovasi, yang bukan sahaja bertumpu pada invensi dan inovasi teknologi-teknologi fizikal, tetapi secara lebih meluas adalah meliputi asal-usul semua leluhur idea-idea yang mencetuskan jalan-jalan baru berfikir dan berkelakuan, bentuk-bentuk baru dalam organisasi sosial, termasuk teknologi-teknologi fizikal yang baru. Perspektif sistem-sistem kreatif nyata begitu meluas, dengan kata lain, mencakupi dari ehwal sosial sehingga teknologi-teknologi fizikal.

Hardt dan Negri melihat keperluan dibangunkan suatu teori politikal baru terhadap nilai, ini disebut dalam bukunya Empire yang menyentuh kebangkitan kreativiti sebagai suatu proses baru yang banyak boleh mengubah; [R]ecent transformations of productive labour have shown a tendency to become increasingly immaterial. The central role previously occupied by the labour power of mass factory workers in the production of surplus value is today increasingly filled by intellectual, immaterial, and communicative labour power (2001: 29). Hardt dan Negri 
berpendapat wujud tiga rencana utama yang boleh disifatkan sebagai 'immaterial labour' yang terkait dengan jaringan informasional: 1) The communicative labour of industrial production, which is linked in informational networks, 2) The interactive labour of symbolic analysis and problem solving, and 3) The labour of the production of the manipulation of affects (2001: 30). Ini diperkuatkan dengan pandangan Sebastian Olma bahawa polisi atau kebijakan industri kreatif menyasarkan suatu a transformation of the structural conditions of production in such a way that 'creativity' (the reference here is to 'individual creativity, skill and talent') can be channelled into regimes of property... the potential for 'collective hallucination' of a creative city based on an ungovernable accumulation of symbolic capital (2007). Maka dapat difahami bahawa bentuk dan kandungan industri kreatif adalah sebuah proses menangani elemen-elemen alamiah yang terdapat dalam tradisi, budaya dan sistem hidup, secara bersama dengan elemen-elemen sains dan teknologi, dengan menggunakan pengetahuan-pengetahuan yang terbaik, dan akhirnya menghasilkan produk-produk yang melengkapkan kehendak, keinginan dan keperluan penghidupan. Penawaran terhadap hasil kreatif dan inovatif dengan mencipta permintaanpermintaan baru. Ini selari dengan apa yang digagaskan oleh Theodor Adorno dan Max Horkheimer (1977) dalam kritikan mereka terhadap industrialisasi budaya sewaktu kemunculan masyarakat kapitalis. Bagi Adorno dan Horkheimer, industrialisasi atas budaya, dan campur aduknya dengan industri kapitalis dan komoditi estetika, bermakna suatu proses bersekutu antara seni tulen (true art) dan budaya, dan perbezaan artifisial terhadap komoditi-komoditi budaya dalam hubungan standardisasi secara keseluruhan dan mass production, yakni technical rationality today is the rationality of domination. It is the compulsive character of a society alienated from itself (2002: 95).

Ekonomi kreatif adalah hasil langsung dari keseluruhan kompleks industri kreatif; dan, industri kreatif adalah proses langsung dari keseluruhan lingkaran komponen-komponen sistem kreatif. Sistem kreatif terbahagi pda 3 bentuk dan kandungan, iaitu:

1. Generatif Kreativiti - yakni, asal-usul idea, yang memerlukan prakarsa penyelidikan dan pembangunan, pemahaman terhadap citarasa, keperluan dan permintaan, memajukan ilham, imaginasi, idealisme, dan prediksi terhadap masadepan; sama ada, cetusan idea didorong oleh sejarah, budaya, warisan, dan teknologi.

2. Adoptif Kreativiti - yakni, proses adopsi dan adapsi terhadap asal-usul idea dan idea tersebut sekali gus menghasilkan proses, acuan-acuan, produk dan sebagainya. Prakarsa percubaan, penciptaan dan pekerjaan dalam menjayakan idea.

3. Retentif Kreativiti - yakni, penciptaan dan penggubahan idea-idea menjadi perkhidmatan atau barangan yang melengkapkan permintaan dan perubahan gaya hidup, atau masa depan.

Setiap hari, para petani, dan ahli keluarga serta sanak saudara mereka di lembah perairan Kemubu di Kelantan sebagai misalannya, bersua dan bergaul, bermain malah berhadapan dengan sawah atau bendang, atau baroh milik mereka. Di dalamnya mungkin berkubang sepilai, haruan, keli dan sepat; paling lazim akan dijoran atau dijala, lalu dijadikan lauk pauk, antara makanan tradisi paling lazat pernah dicipta seperti asam pedas, bakar pais, pekasam, bakar dan cicah asam. Lalu sikap terhadap ikan sepat, sepilai, haruan dan keli tadi dalam mayatilik 'seorang belia' tibatiba berubah, dari sekadar memahaminya sebagai lauk pauk akhirnya beliau mengambil dahan- 
dahan manggis, batang-batang kelapa yang tumbang lalu 'diukir', 'dipahat' dan jadilah perhiasanperhiasan kraf untuk digunakan dan dihiaskan di rumah-rumah. Akhirnya idea ini berkembang dan 'belia' inipun mula menggunakan material-material baru seperti perak dan emas yang sememangnya menjadi sebahagian perkara penting dalam budaya hidup masyarakat Kelantan, dan dibikinkan gelang-gelang, rantai-rantai perhiasan dari imej sepilai, haruan, sepat dan keli. Sambutan terhadap kreativiti beliau ini akhirnya menjadikan 'Kampung Muring' di Perairan Kemubu itupun terkenal di serata dunia, dan akhirnya melonjakkan keseluruhan industri kreatif yang pelbagai akhirnya. Inilah gambaran bentuk dan kandungan sistem kreatif originatif/generatif, adoptif dan retentif. Samalah bagaimana novel idea tentang kopi akhirnya melonjakkan segala macam industri kreatif di Eropah, misalnya di Vienna, Austria. Penjanaan sistem ini tentulah berlaku serentak dengan kemampuan untuk memahami masasilam, menangani masa kini dan menguruskan masa depan.

The creative system is not an industry, but rather a component of all industries. Second, it makes sense of the dominance of the creative industries by economic activities devoted to adoption and retention processes. Creativity is not just something that happens at the beginning of a technology trajectory, when a new idea is hatched or discovered, but continues throughout the trajectory until the novel idea is completely embedded in the economic and social order and becomes a normalised part of the knowledge base.

(Potts 2006: 11)

Malaysia yang cukup terkenal dengan sumberdaya-sumberdaya warisan; sama ada yang ditafsirkan dari komponen budaya, seni, tradisi, adat, dan amalan-amalan seharian mahupun hasil mahsul bumi seperti tumbuh-tumbuhan, galian-galian, bahan-bahan semulajadi yang lain cukup untuk menjadi laboritorium industri kreatif yang terbaik, sebagaimana rancaknya perkembangan industri kreatif ini di Eropah Tengah seperti Austria, Slovakia, Estonia, Lithuania dan Armenia, termasuk Bosnia dan lingkaran Balkan.

Since the end of the 1990s, studies about Creative Industries have been carried out throughout Europe - both at national and regional levels and also cross-national analyses have been conducted. A comparison of the available publications shows that the understanding of the sector, and even the terminology (Creative Industries vs. Cultural Industries) - varies from country to country and also within countries the definitions differ from region to region. Reasons for those differences are, forexample, the historical development of countries/regions or different orientations concerning national cultural politics (keyword: "path dependency").

(Hölzl 2008) 


\subsection{Kelas Kreatif - Bakat, Teknologi Dan Toleransi}

Industri kreatif, secara filsafatnya adalah sebuah kompleks pembangunan ekoposial dalam Kurun 21, yang terkesan dari perkembangan perusahaan pelancongan, industri teknologi maklumat dan media, dan informasi khususnya kemunculan pasaran media sosial atau sosialsfera yang dapat dirumuskan sebagai Tri-Sektor Model iaitu publik/umum, intermediat/komuniti, dan swasta/pengusaha.

1. Sektor Publik/Umum meliputi pengusaha-pengusaha budaya umum atau awam seperti panggung-panggung kesenian, opera-opera, muzium, teater-teater, galeri-galeri budaya atau pentas persembahan tradisi dan warisan.

2. Sektor Intermediat/Komuniti melibatkan organisasi-organisasi non-profit seperti persatuan-persatuan, pertubuhan-pertubuhan, kelab-kelab, yayasan-yayasan yang menguruskan pendidikan dan pemajuan kreativiti melalui latihan dan bimbingan serta penghasilan kesenian, kebudayaan dan seumpamanya.

3. Sektor Swasta/Swadaya/Perniagaan merupakan entiti-entiti yang aktif dalam produksi atau penghasilan produk kreatif, terlibat dalam pemasaran barangan dan perkhidmatan kreatif secara komersial. 
Jadual 1 : Kelas Kreatif : Bakat, Teknologi dan Toleransi.

\begin{tabular}{|c|c|c|c|c|c|c|c|c|c|c|}
\hline & UK & Austria & Finland & Germany & Spain & \multicolumn{2}{|c|}{ France } & $\mathbf{E U}$ & $\begin{array}{l}\text { Switzer- } \\
\text { land }\end{array}$ & Hungary \\
\hline Term used & $\begin{array}{l}\text { Creative } \\
\text { Industries }\end{array}$ & $\begin{array}{c}\text { Creative Industries } \\
\text { Austria/Vienna }\end{array}$ & $\begin{array}{l}\text { Creative } \\
\text { Industries }\end{array}$ & $\begin{array}{l}\text { Culture } \\
\text { Industries }\end{array}$ & $\begin{array}{l}\text { Culture } \\
\text { Industries } \\
\text { (Industrias } \\
\text { culturales) }\end{array}$ & $\begin{array}{l}\text { Culture } \\
\text { Industries } \\
\text { (Industries } \\
\text { Culturelles) }\end{array}$ & $\begin{array}{l}\text { Cultural } \\
\text { Sector } \\
\text { (Secteur } \\
\text { culturel) }\end{array}$ & $\begin{array}{l}\text { Cultural } \\
\text { Sector }\end{array}$ & $\begin{array}{l}\text { Culture or } \\
\text { Creative } \\
\text { Industries }\end{array}$ & $\begin{array}{c}\text { Culture or } \\
\text { Creative } \\
\text { Industries } \\
\text { (often used } \\
\text { synonymously) }\end{array}$ \\
\hline
\end{tabular}

\begin{tabular}{|c|c|c|c|c|c|c|c|c|c|c|c|}
\hline \multicolumn{12}{|l|}{ Industry } \\
\hline Architecture & $\mathrm{x}$ & Visual arts & $\mathrm{x}$ & $\mathrm{x}$ & $\begin{array}{l}\text { x (excl. } \\
\text { Cologne) }\end{array}$ & & & $\mathrm{x}$ & $\mathrm{x}$ & $\mathrm{x}$ & $\mathrm{x}$ \\
\hline Archives & $\mathrm{x}$ & $\begin{array}{l}\text { Cultural } \\
\text { heritage }\end{array}$ & $\mathrm{x}$ & & & $\mathrm{x}$ & & $\mathrm{x}$ & $\mathrm{x}$ & $\begin{array}{l}\text { Literaturel } \\
\text { publishing }\end{array}$ & $\begin{array}{l}\mathrm{x} \text { (Culture } \\
\text { Industries) }\end{array}$ \\
\hline $\begin{array}{r}\text { Audio-visual field (film, } \\
\text { TV, radio) }\end{array}$ & $\mathrm{x}$ & $\mathrm{x}$ & $\mathrm{x}$ & $\mathrm{x}$ (media) & $\mathrm{x}$ & $\mathrm{x}$ & $\mathrm{x}$ & $\mathrm{x}$ & $\mathrm{x}$ & $\mathrm{x}$ & $\mathrm{x}$ \\
\hline Libraries & & $\begin{array}{l}\text { Cultural } \\
\text { heritage }\end{array}$ & $\mathrm{x}$ & & & $\mathrm{x}$ & & $\mathrm{x}$ & $\mathrm{x}$ & $\begin{array}{l}\text { Literature/ } \\
\text { publishing }\end{array}$ & $\begin{array}{l}\mathrm{x} \text { (Culture } \\
\text { Industries) }\end{array}$ \\
\hline Performing arts & $\mathrm{x}$ & $\mathrm{x}$ & $\mathrm{x}$ & $\mathrm{x}$ (theatre) & $\mathrm{x}$ & $\mathrm{x}$ & & $\mathrm{x}$ & $\mathrm{x}$ & $\mathrm{x}$ & $\mathrm{x}$ \\
\hline Design & $\mathrm{x}$ & Visual arts & $\begin{array}{c}\mathrm{x}(\mathrm{a} \text { and } \\
\text { graphic } \\
\text { arts })\end{array}$ & & $\begin{array}{c}\text { x (NRW, } \\
\text { Aachen, } \\
\text { Cologne) }\end{array}$ & & & & $\mathrm{x}$ & $\mathrm{x}$ & $\mathrm{x}$ \\
\hline Craftwork & $\mathrm{x}$ & & & $\mathrm{x}$ & x (Hesse) & & & & & $\mathrm{x}$ & $\mathrm{x}$ \\
\hline Art market & $\mathrm{x}$ & Visual arts & $\mathrm{x}$ & & $\mathrm{x}$ & & & $\mathrm{x}$ & & $\begin{array}{l}\mathrm{x}(+ \text { fine } \\
\text { arts })\end{array}$ & $\mathrm{x}$ \\
\hline
\end{tabular}


Jadual 1 :...sambungan

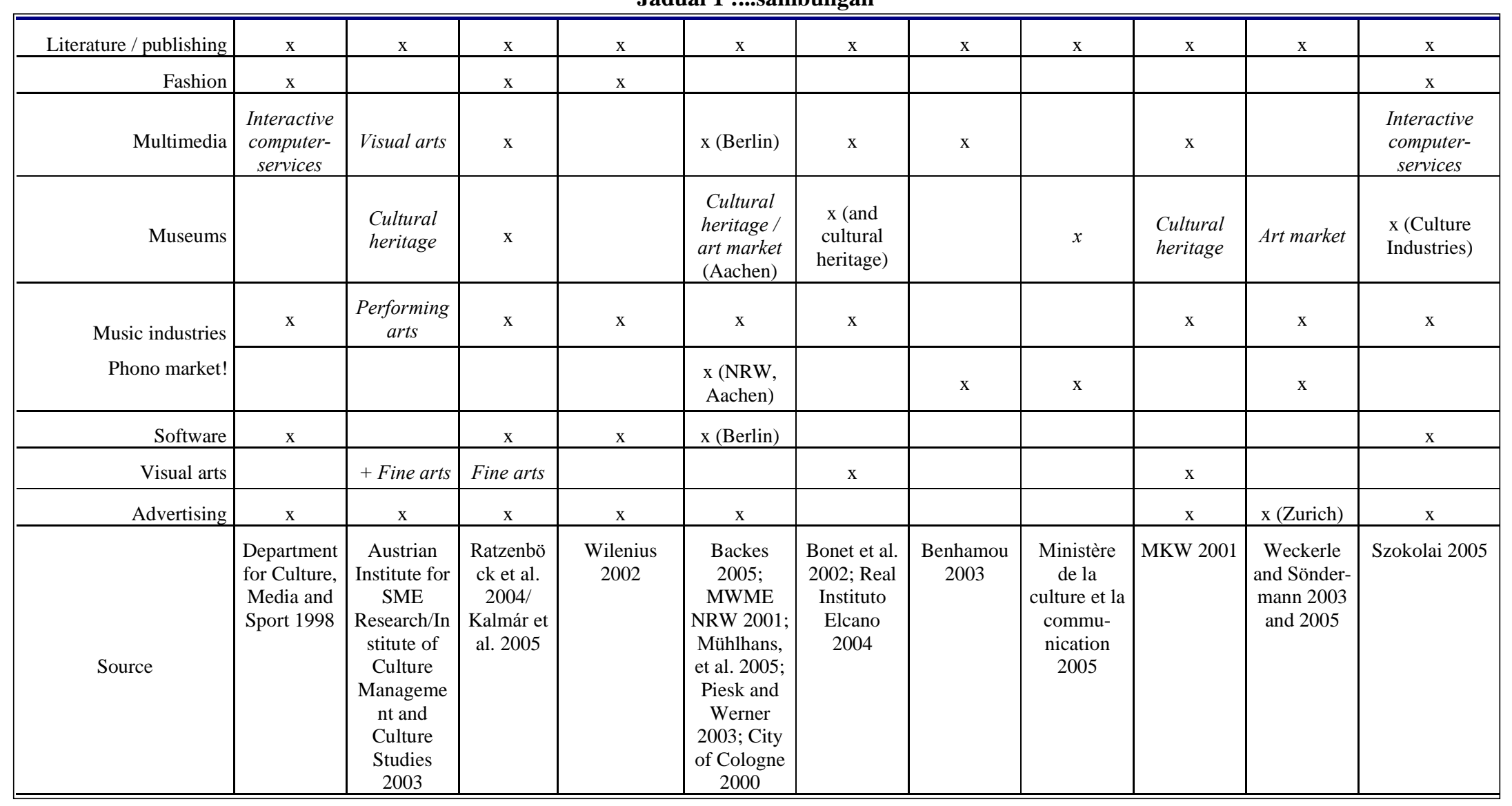


Secara ringkasnya dapat digambarkan melalui jadual LIKUSkreativ@-scheme ini:

Jadual 2 : LIKUSkreativ@-scheme

Sumber : Mandl, dll (2006:34)

\begin{tabular}{|l|l|}
\hline \multicolumn{1}{|c|}{ LIKUSkreativ $^{\circ}$-domain } & \multicolumn{1}{c|}{ LIKUSkreativ ${ }^{\circ}$-category } \\
\hline Cultural heritage & Museums, archives, science \\
& Historical monuments and sites \\
& Folk arts, local history and customs \\
& Libraries \\
\hline Performing arts & Music \\
& Theatre, opera, musicals, dance \\
\hline Audio and audiovisual & Film, cinema, video \\
& Radio, television \\
\hline Visual arts & New media \\
\hline Books and press & Fine arts, photography \\
& Architecture \\
& Applied arts, graphic arts, design \\
\hline Interdisciplinary & Literature \\
& Newspaper, periodicals \\
\hline & Initiatives, cultural centres \\
& Training, further education \\
& Adult education \\
& International exchange \\
& Large-scale events \\
& Administration \\
\hline
\end{tabular}

Malaysia tentulah memiliki keupayaan dari sumberdaya-sumberdaya yang ada untuk muncul sebagai laboriorium kreatif dunia. Namun kepercayaan ini hendaklah dimajukan dengan melahirkan apa yang disebut oleh Richard Florida (2002: 220) sebagai 'Creative Clas' atau Kelas Kreatif. Ini kerana dalam lumrah ekonomi, perkembangan berlaku secara regional, berlainan di antara setiap desa-desa, pekan-pekan, kota-kota, daerah-daerah, jajahan-jajahan, antara setiap negeri, malah negara-negara dan antara setiap sempadan-sempadan geografi dan budaya. Dalam kata yang lain, dari sisi mayatilik tradisional perkembangan ekonomi ini dapat difahamkan sebagai places grow either because they are located on trasportation routes or because they have endowments of natural resources that encourage firms to locate there (Florida 2002: 221). Kemudiannya melalui Human Capital Theory atau Teori Modal Insan, mencadangkan faktorfaktor dorongan dari amalan ekonomi klasik seperti pengurangan kos, penghapusan cukai, pemajuan infsratruktur perlu diganti dengan perhatian terhadap melahirkan modal insan berpengetahuan dan berkemahiran tinggi berbanding penggunaan buruh-buruh kasar yang lazim (Thomas \& Damton 2006: 154). Lalu Florida melalui teori Kelas Kreatif menjelaskan on regional growth theories focussed on knowledge-based, cluster-oriented and technology-led job growth (Holzheimer \& Hodgin 2005: 1). Beliau melihat secara serius peranan yang dimainkan oleh 'teknologi' dan 'bakat', atau yang dimaksudkan sebagai 'modal insan', dalam pembangunan ekonomi, namun tidaklah bermaksud as stocks that accumulate in regions or nations (Florida, gates, Knudsen \& Stolarick 2006: 5). Florida mencadangkan ianya hendaklah suatu perwatakan 
partikular bagi setiap tempat dengan menawarkan tarikan-tarikan dari faktor-faktor ini - the openness of a place to new ideas and new people (Florida, gates, Knudsen \& Stolarick 2006: 5). Teori Kelas Kreatif menggaris bawahi bentuk, kandungan dan sistem industri kreatif tersebut, yakni:

regional economic growth is driven by the location choice of creative people - the holders of creative capital - who prefer places that are diverse, tolerant and open to new ideas

(Florida 2002: 223)

Matlamat menjadikan Malaysia sebagai laboritorium kreatif, adalah sama dengan keperluan melahirkan Kelas Kreatif secara serius dan mengisi asas-asas utama dalam polisi ekoposial. Kelas Kreatif seperti yang dikatakan oleh Florida adalah pekerja-pekerja kreatif, yang hanya boleh diwatakkan melalui valuing individuality, meritocracy, diversity and openness (2002: 77). Ini kerana di masakini, mengikut Florida, today people are increasingly concerned with what life is all about (2002: 81-82). Industri kreatif yang telah diterima sebagai suatu kebangkitan masakini dalam mencorakkan dan membina ekoposial masa depan, terutama dalam perubahan-perubahan cara hidup yang terkesan dari ledakan teknologi maklumat dan informasi, yang mencetuskan perubahan dalam cara manusia menguruskan penghidupan akhirnya mengembalikan hubungan ekonomi tradisional dengan nilai-nilai seni, budaya, sejarah, sumber-sumber alam dengan keupayaan pengetahuan yang tinggi bersama dengan teknologi akhirnya menjadikan kreativiti dan inovasi sebagai faktor-faktor kualiti hidup. Kreativiti, inovasi menjadi asas pembinaan kualiti hidup, dengan faktor-faktor kualiti tempat, yakni:

what's there - "the combination of the built environment and the natural environment, a proper setting for pursuit of creative lives";

who's there - "the diverse kinds of people, interacting and providing cues that anyone can plug into and make a life in that community"; who's going on - "the vibrancy of street life, café culture, arts, music and people engaging in outdoor activities - altogether a lot of active, exciting, creative endeavours"

Industri kreatif akan terbentuk sebaik terbentuknya Kelas Kreatif, dan tentulah Kelas Kreatif ini tidak sekadar wujud secara lahiriah, dengan bakat-bakat 'sakti' dan 'ajaib' dari rahmat-rahmat atau keramat-keramat sejak dilahirkan. Kelas Kreatif adalah sebuah masyarakat yang terhasil dari suatu proses kependidikan, dan pengluasan pengetahuan secara berterusan serta dapat mengamalkan pengetahuan-pengetahuan tadi secara teoritikal dan praktikal dalam suasana tempat yang harmoni, terbuka dan berpartisipasi. Kelas Kreatif muncul dari kualiti/mutu keadaan sesuatu tempat dan barulah ekonomi kreatif akan tercipta dan masa depan dibangunkan selari dengan dinamikanya. Maka itulah dalam makalah ini, secara ketatnya diangkat pandangan Florida sebagai rumusan, yakni penglahiran Kelas Kreatif. Kelas Kreatif mengikut Florida adalah teradiluhung dari rukun 3T - Talent, Technology, Tolerance. 


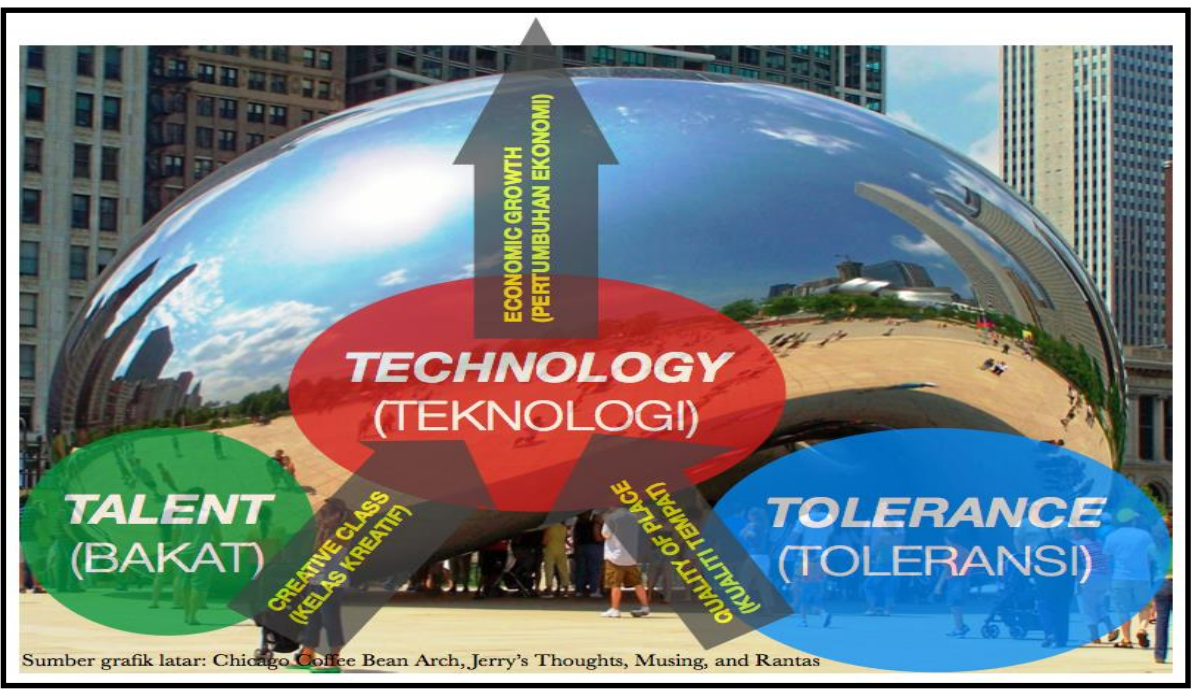

Rajah 2 : 3T - Talent, Technology, Tolerance

Kelas Kreatif muncul dari kekuatan fungsi ekonomi both underlins and informs its members' social, cultural and lifestyle choices (Florida 2002: 68). Jadi, the Creative Class consists of people who add economic value through their creativiti; dan the distinguishing characteristic of the Creative Class is that its members engage in work whose function is to "create meaningful new forms"'(2002: 68-69). Florida membahagikan Kreatif Kelas pada 2 komponen yang berasaskan keterlibatan mereka dalam kerja-kerja kreatif, iaitu:

1. Kelas Super Creative Core - computer and mathematical occupations, architecture and engineering occupations, life, physical and social science occupations, education, training and library occupations, art, design, entertainment, sports and media occupations (Florida 2002: 328)

2. Kelas Creative Professsionals - management occupations, business and financial operations occupations, legal occupations, healthcare practitioners and technical occupations, high-end sales and sales managers (Florida 2002: 328)

Kesimpulannya, dalam model Kelas Kreatif ini, Florida menyatakan bahawa komponenkomponen utamanya adalah teknologi, bakat dan toleransi kerana ketiga-tiga elemen ini menjadi struktur dalam mewujudkan magnetisme atau gravitas antara modal insan, situasi tempat dan lingkaran ekonomi. Ini diperkukuhkan lagi bila teknologi informasi akhirnya mewujudkan sosialsfera yang sekali gus menuntut perwatakan teknologi, bakat dan toleransi ini. Bagi Florida masa depan adalah understanding the new economic geography of creativity and its effects on economic outcomes; dan each is a necessary but by itself insufficient condition: To attract people, generate innovation and stimulate economic growth, a place must have all there (Florida 2002: 249).

Menjadikan Malaysia sebagai laboritorium kreatif akan berjaya sekira mengadiluhung hubungan bakat, teknologi dan toleransi ini. Teknologi bergantung pada pencipta-pencipta berkemahiran tinggi; manakala, bakat adalah graviti asas dalam penciptaan, pembangunan dan penggunaan teknologi; manakala toleransi adalah keharmonian dengan budaya bersekutu buat perubahan, perkongsian, kesepakatan dan kebersamaan meski berbagai-bagai (majemuk dan 
diversitas), yakni "environment open to new people and ideas". (Florida 2002: 249). Seumpama sebuah warong kopi, semua orang hadir di dalamnya menikmati kopi, sebahagian mendapat ideaidea, dibangunkan, dimajukan, dan menghasilkan produk-produk barangan dan perkhidmatan, dan kemudian dipasarkan, lalu membentuk penghidupan yang sejahtera dengan kepelbagaian, kesaksamaan dan penghidupan baru yang membina masa depan.

Industri kreatif adalah sebuah projek ekonomisasi (economization) ekoposial masa depan, dengan kepantasan hentakan kesan-kesan globalisasi khususnya kelakuan migrasi masyarakat, dengan sebahagian modal insan yang cekap, bijak dan budiman bergerak ke negara-negara yang lebih saksama, terbuka dan demokratis; manakala di waktu yang sama membanjirnya pekerjapekerja pendatang yang berpendidikan rendah, tidak berkemahiran tentulah memerlukan sebuah metamorfosis dari semua komponen sistem penghidupan setiap masyarakat dan negara itu. Tentulah mendepani segala-gala perubahan dalam pendidikan, dengan perhatian pada sains secara total tidak akan membawa faedah sekira tidak menempatkan pemikiran sosial yang merupakan ruh bagi setiap proses kreatif sebagai penting, dan perlu didominankan. Projek inilah yang dapat difahamkan sebagai rencana melahirkan Kelas Kreatif yang terbaik, yang akan membawa prospek masa depan.

Sebagai projek industri kreatif, dan visi untuk menjadikan Malaysia yang sudah pun majmuk/plural yang menggambarkan kekayaan sumberdaya-sumberdaya inovasi sebagai laboritorium kreatif dunia, atau di rantau Asia tentulah suatu rencana pemajuan metodologi atau dasar perlu dilakukan, dengan membina lingkaran ekonomi kreatif nasional. Mungkin projek CREATIVE METROPOLES yang dimajukan di Eropah boleh menjadi contoh dalam menjayakan matlamat projek ini.

The INTERREGIVC funded project CREATIVE "METROPOLES 'aims to strengthen the capacity and effectiveness of public sector to unlock and support the economic potentialofthe creative economy'. The project proposal used the term creative industries $(\mathrm{CI})$ and defined creative industries as "those origin in individual creativity, skill and talent and which have a potential for wealth and job creation through the generation and exploitation of intellectual property".

"The partnership of the project is constituted by municipalities and development agencies of metropolitan cities in Europe, which play a central role in the economies of their regions and countries. These cities are Amsterdam, Barcelona, Berlin, Birmingham, Helsinki, Oslo, Riga, Stockholm, Tallinn, Vilnius and Warsaw. These cities are rather different in their approach to the creative industries as to their experiences in supporting these industries. Therefore understanding the context of each city is considered highly relevant throughout the whole project".

(Creative Metropoles 2009: 1) 
Merealisasikan projek Kelas Kreatif, dengan mengambil contoh dari projek Creative Metropoles Erurope ini wajar sekali bagi memudahkan dalam memahami ekonomi kreatif.

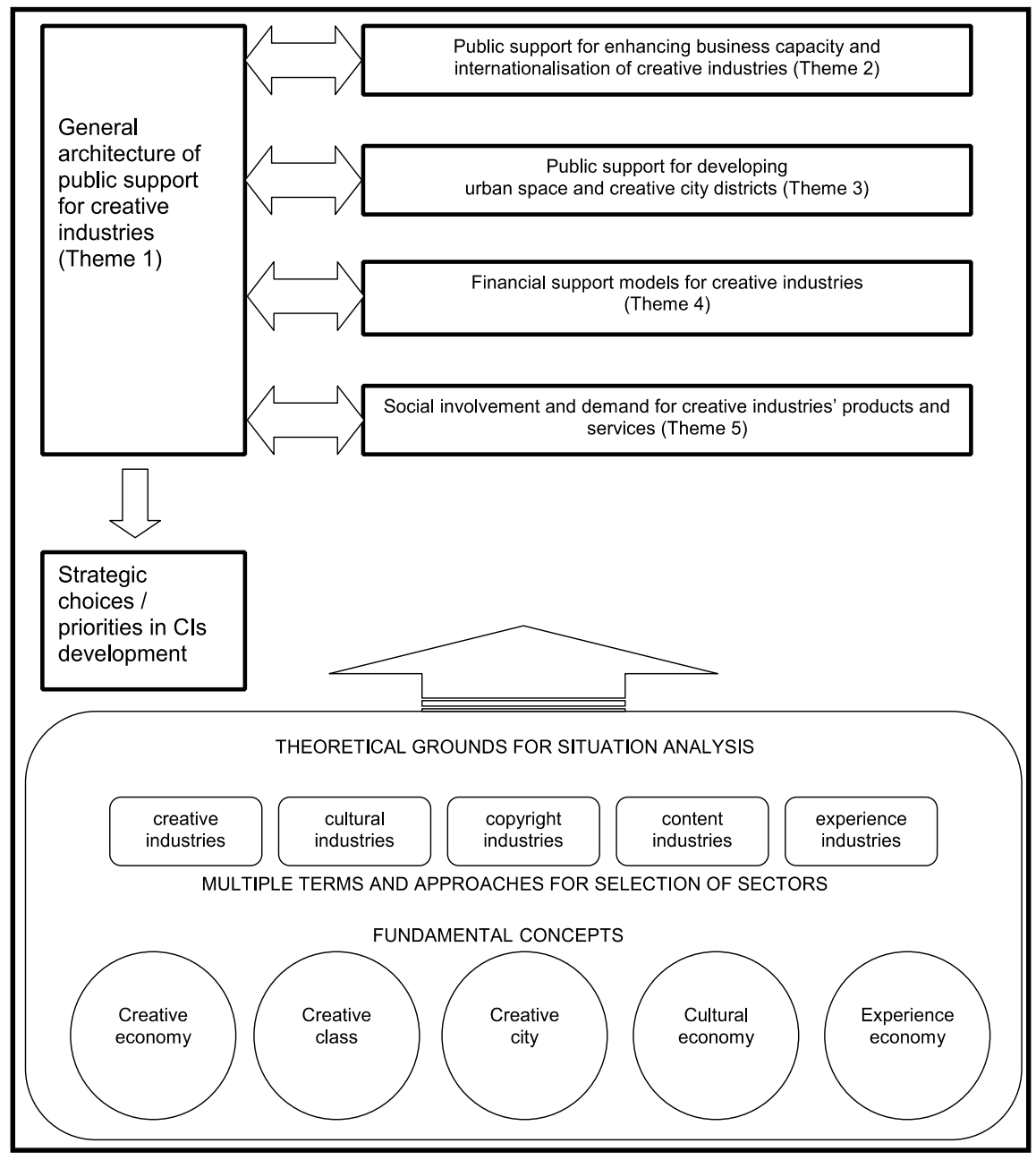

\section{Diagram Rangkaprojek CREATIVE METROPOLES EUROPE Sumber rajah: (CREATIVE METROPOLES 2009: 10)}

Malaysia dengan kemajemukan tradisi, warisan, kepercayaan, budaya akan sendirinya memiliki potensi untuk menguasai ekonomi kreatif, namun projek melahirkan Kelas Kreatif hendaklah di laboritorium dengan pantas dan cermat, bagi membolehkan ruang-ruang industri kreatif dimanfaatkan sepenuhnya. 


\section{Rujukan}

Adorno, T. \& Max Horkheimer (1994). The Culture Industry: Enlightenment as Mass Deception. Dlm. J. Curran, M. Gurevitch dan J. Woollacott (Ed), Mass Communication and Society (pp. 94-136 ). London: Edward Arnold.

Agrey, L. (2004). The Pressure Cooker in Education: Standardized Assessment and High-Stakes. Dlm. A. Foran Canadian Social Studies (pp. 1-12). Canada:St Francis Xavier University.

Alanen, Aku. (2004). Taiteilijapolitiikka ja luovuus (Art politics and Creativity). Jyväskyla: University of Jyväskyla.

Allen, J. \& Paul du Gay. (1994). Industry and the Rest: The Economic Identity of Services. Work, Employment \& Society, 8(2), 255-271.

Allen, K. \& P. Shaw (2001). Continuing Professional Development for the Creative Industries: A Review of Provision in the Higher Education Sector. London: Higher Education Funding Council for England.

Almhofer, E.,G. Lang, G. Schmied \& G. Tucek (2000). Die Hälfte des Himmels. Chancen und Bedürfnisse kunstschaffender Frauen in Österreich. (Half of the sky. Chances and Needs of Female Creative Artists in Austria). Vienna: Dea Skriptum.

Alton, J. \& S. Benzer, Sabine (ed). (2005). Creating the Change - Frauenstudie der IG Kultur Vorarlberg. Wien: Feldkirch.

Amabile, Teresa M. (1992). Growing Up Creative. Dlm. Creative Education Foundation (pp.77 99 )

Amabile, Teresa M. (1998, Sept-Oct). How to Kill Creativity. Harvard Business Review, 77-87.

ARGE Baukulturreport (ed). (2006). Österreichischer Baukulturreport (Austrian Report on Building Culture). Vienna: ARGE.

Australian Bureau of Statistics (2001). Australian Culture and Leisure Classifications. Adelaide: Australian Bureau of Statistics.

Barrière, C., \& W. Santagata (1997). AIMAC Proceedings: Defining Art, From the Brancusi Trail to the Economics of Semiotic Goods. San Francisco: Golden Gate University.

Benhamou, F. (2003). L'économie de la culture (The economy of culture). Paris: Éditions la Découverte.

Bennett, T. (1982). Theories of Media, Theories of Society. Dlm. M. Gurevitch, T. Bennett, J. Curran and J. Woollacott (Eds), Culture, Society and the Media (pp. 11-24). London: Methuen.

Bennett, T. (1998). Culture: A Reformer's Science. Sydney: Allen \& Unwin.

Bennett, T. dll. (ed). (1981). Culture, Ideology and Social Process. Batsford: Batsford Academic and Educational.

Bilton, C. \& R. Leary (2004). What can managers do for creativity? Brokering creativity in the creative industries. International Journal of Cultural Policy,8(1), 49-64.

Bonet, L., Albert de Gregorio, \& Anna Villarroya (2002). Handbook on the Cultural Industries of Catalonia. Summary and conclusions. Barcelona: Institut català de les industries culturals/Universitat de Barcelona.

Brecknock, R. (2004). Creative Capital: Creative Industries in the Creative City. London: Brecknock Consulting PLI.

Breen, M. (1999). Rock Dogs: Politics and the Australian Music Industry. Sydney: Pluto Press. British Council Creative Industries Unit (2004). Creative Industries. London: British Council. 
British Council. (1998). Britain's Design Industry: The Design Workshop of the World. London: British Council.

Bundesministerium für auswärtige Angelegenheiten.Auslandskultur Neu. (New Foreign Culture). Vienna (2001).: $h t t p: / / w w w$. aussenministerium.at/view.php3? $r_{-} i d=51 \& L N G=$ de \&version $=$

Bundesministerium für europäische und internationale Angelegenheiten.Außenpolitischer Bericht (2007). der Bundesregierung. (Report with Regard to Foreign Policy 2007). Thomas Schlesinger, dll. (ed). Vienna, 2009: http:// www. parlament.gv.at/PG/DE/BR/IIIBR/IIIBR_00351/pmh.shtml

Bundesministerium für Unterricht, Kunst und Kultur, Kunstsektion.Kunstbericht (2008). Bericht über die Kunstförderung des Bundes. (Art Report 2008. Report on Art Promotion of the Federal Government).Herbert Hofreither, Robert Stocker (ed). Vienna, 2009: http://www. bmukk.gv.at/medienpool/18174/kunstbericht2008.pdf

Bundesministerium für Unterricht, Kunst und Kultur, Sektion Kultur.Kulturbericht 2008. (Culture Report 2008).Michael P. Franz dll. Vienna, 2009:http://www.bmukk.gv. at/medienpool /18173/kulturbericht2008.pdf

Bundesministerium für Unterricht, Kunst und Kultur.Newsletter Kunst / Kultur: http://bmukkkunst-kultur.at/

Calhoun, C., E. Lupuma, \& M. Postone (1993). Bourdieu Critical Perspectives. Great Britain: Polity Press.

Castells, M. (1996). The Rise of the Network Society, Vol. 1 of The Information Age: Economy, Society and Culture. Massachusetts: Blackwell.

Caust, J. (2003). Putting The "Art" Back Into Arts Policy Making: How Arts Policy Has Been "Captured" By The Economists And The Marketers. International Journal of Cultural Policy, 9(1), 51-63.

CAVES, R. (2000). Creative Industries: Contracts between Art and Commerce. London: Harvard University Press.

Caves, R. (2000). Creative Industries. Cambridge, Mass: Harvard University Press.

City of Cologne. (2000). Kulturwirtschaftsbericht Köln (Report on Cultural Industries Cologne). Cologne: City of Cologne.

Committee of Youth, Education, the Media and Sport. (2003). Draft Report on Cultural Industries. Belgium: European Parliament.

Conomos, J. (1996). At the End of the Century: Creative Nation and New Media Arts. Continuum: The Australian Journal of Media and Culture, 9(1), 118-129.

Court, D. (1994, November). Capture Theory and Cultural Policy. Media Information Australia, 73, 23-25.

Cunningham, S. (2002). From Cultural to Creative Industries, Theory, Industry, and Policy Implications. Brisbane: Creative Industries Research and Applications Centre, University of Technology Brisbane.

Cunningham, S., G. Hearn, S. Cox, A. Ninan, \& M. Keane (2000). Brisbane's Creative Industries 2003. Report delivered to Brisbane City Council, Community and Economic Development. Brisbane: Creative Industries Applied Research Centre, Queensland University of Technology.

Davis, H. \& Scase, R. (2000). Managing Creativity. Buckingham: Open University Press.

DCMS. (1998). Creative Industries Mapping Document. London: DCMS.

DCMS. (2001). Creative Industries Mapping Document. London: DCMS. 
Drucker, P. (1999). Harvard Business Review on Breakthrough Thinking. Berkeley: Harvard Business School Press.

Ellmeier, A., Baumgartner, G. dan Perchinig, B.Transversal Study: Cultural Policy and Cultural Diversity. Strasbourg: Council of Europe, 2001

Ellmeier, A., Ratzenböck. V. (1999). Cultural Competence. New Technologies, Culture \& Employment. Vienna: österreichische kulturdokumentation. internationales archiv für kulturanalysen.

European Union. (2000). Cultural Statistics in the EU. Final Report of LEG. European: European Union

Evans, G. (1997). Measuring the Arts and Cultural Industries - Does Size Matter?. Dlm. S. Roodhouse (Ed.) The New Cultural Map: a Research Agenda for the 21st Century (pp. 914). Wakefield: University of Leeds.

Featherstone, Mike. (1991). Consumer Culture and Postmodernism. London: Sage.

Flew, T. (2002). The Second International Conference on Cultural Policy Research: Beyond ad hocery: Defining Creative Industries. 23-26 January. Te Papa, Wellington, New Zealand.

Flew, T., G. Ching, A. Stafford, \& J. Tacchi (2001). Music Industry Development and Brisbane's Future as a Creative City. Brisbane: CIRAC, Queensland University of Technology.

Florida, R. (2005). The Flight of the Creative Class. New York: Harper Business.

Florida, R. (2002). The Rise of the Creative Class. New York: Basic Books.

Frank, B. (2005). Kreativbranchen in Berlin (Creative Industries in Berlin). Berlin: DIW.

Fränzen, B., dan Hufnagl, C. (2008). Innovative Film Austria.Vienna: Federal Ministry for Education, Arts and Culture, Vienna.

Galloway, S. (2003). Employment in Scotland Cultural Sector 1998-2001 - A CCPR Briefing Paper. Glasgow: Glasgow University, Centre for Cultural Policy Research,.

Gardner, H. (1994). Creating Minds: An Anatomy of Creativity Seen Through the Lives of Freud, Einstein, Picasso, Stravinsky, Eliot, Graham, and Gandhi. New Rork: Basic Books.

Garnham, N. (1997). Concepts of Culture: Public Policy and the Cultural Industries. Cultural Studies, 1(1), 23-37.

Garnham, N. (2005). From Cultural To Creative Industries. International Journal of Cultural Policy, 11(1), 15-29.

Garnham, N. (1990). Capitalism and Communication: Global Culture and the Economics of Information. London: Sage.

Garnham, N. (2000). Emancipation, the Media, and Modernity: Arguments about the Media and Social Theory. Oxford: Oxford University Press.

Grant, P. S. \& Wood, C. (2004). Blockbusters and Trade Wars: Popular Culture in a Globalised World. Columbia: Douglas and McIntyre.

Hartley, J. (ed). (2002). Creative Industries. Oxford: Blackwell.

Hesmondhalgh, D. \& Pratt, A. C. (2005). Cultural Industries And Cultural Policy. International Journal of Cultural Policy,11(1), 1-13.

Hesmondhalgh, D. (2002). The Cultural Industries. London: Sage.

Horkheimer, M. \& Adorno, T.W. (2002). The Culture Industry: Enlightenment as Mass Deception. Dlm. G. Noerr, T. E. Jephcott (Eds), Dialectic of Enlightenment Philosophical Fragments (pp. 121-142). Stanford: Stanford University Press.

Howkins, J. (2001). The Creative Economy: How People Make Money From Ideas. London: Allen Lane. 
Johansson, F. (2004). The Medici Effect: Breakthrough Insights at the Intersection of Ideas, Concepts, and Cultures. Berkeley: Harvard Business School Press.

Kahn-Harris, K. (2006). Extreme Metal. New York: Berg.

Knapp, M. (2005, May 23). "Österreichische Kulturpolitik und das Bild der Kulturnation. Kontinuität und Diskontinuität in der Kulturpolitik des Bundes seit 1945. Series: Politik und Demokratie, 4.

Kock, S. (2009). Prekäre Freiheiten.Arbeit im freien Theaterbereich in Österreich. Vienna: IG Freie Theaterarbeit.

Lacroix, J-G. \& Tremblay, G. (1997). The Information Society and Cultural Industries Theory. Current Sociology, 48(4), 1-162.

Lampel, J., Lant, T. \& Shamsie, J. (2000). Balancing Act: Learning Organizing Practices in Cultural Industries. Organization Science, 11(3), 263-69.

Landry, C. (2000). The Creative City: A Toolkit for Urban Innovators. London: Earthscan.

Lash, S. dan Urry, J. (1994). Economies of Signs and Space. London: Sage.

Lash, S. \& Urry, J. (2004). Economies of Signs and Space. London: Sage.

Leadbeater, C. (1999). Living on Thin Air: The New Economy. London: Viking.

Leadbeater, Charles \& Kate Oakley (1999). The Independents: Britain's New Cultural Entrepreneurs. London: Demos, Redwood Books.

Leadbetter, C., \& K. Oakley (1999). The Independents: Britain's New Cultural Entrepreneurs. London: Demos, Redwood Books.

Lewin, R. (1988). In the Age of Mankind. Washington DC: SmithsonianBooks.

Lewis, J. (1990). Art, Culture and Enterprise: The Politics of Art and the Cultural Industries. London: Routledge.

Lovatt, A. \& O'Connor, J. (1995). Cities and the Night-time Economy. Planning Practice and Research, 10(2), 127-133.

Mandl, I., Aliette Dörflinger, Karin Gavac, Kerstin Hölzl, Caroline Krupp, \& Heimo Konrad. (2006). Zweiter Österreichischer Kreativwirtschaftsbericht (Second Austrian Report on CI). Vienna: Federal Chancellery, Federal Ministry of Economics and Labour of the Republic of Austria, Austrian Federal Economic Chamber.

Mandl, I., Karin Gavac, Ernst Gittenberger, Franz-Otto Hofecker, Isabella Kamptner, Gregor Kremser, Caroline Krupp, Irene Mandl, Sabine Peternell, Romy Sagmeister, Peter Voithofer, Nadine Wille \& Christina Wolf (2003). Erster Österreichischer Kreativwirtschaftsbericht (First Austrian Report on CI). Vienna: Federal Chancellery, Federal Ministry of Economics and Labour of the Republic of Austria, Austrian Federal Economic Chamber.

Mattelart, A. \& Piemme, Jean-Marie. (1992). Cultural Industries: The Origins of an Idea. Dlm. UNESCO (Ed).Cultural Industries: A Challenge for the Future of Culture (pp. 50-100). Paris: UNESCO.

Miège, B. (1989). The Capitalisation of Cultural Production.New York: International General.

Ministry of Economic Affairs and Energy of the State of North Rhine-Westphalia (2002). 4th Culture Industries Report. Düsseldorf: Ministry of Economic Affairs and Energy of the State of North Rhine-Westphalia.

MKW Wirtschaftsforschung GmbH (2001). Exploitation and Development of the Job Potential in the Cultural Sector in the Age of Digitalisation. Munich/Vienna: MKW/European Commission.

MKW Wirtschaftsforschungs GmbH, Österreichische Kulturdokumentation (2001). Internationales Archiv für Kulturanalysen et al: Exploitation and Development of the Job Potential in 
the Cultural Sector in the Age of Digitalisation. Munich, Vienna, dll: Comm. by the European Commission, DG Employment and Social Affairs.

Mühlhans, T., Wolfgang Abramowski, Cornelia Dümcke, Anne Rottig, Rainer Schmock-Bathe, \& Konrad Schmidt-Werthern (2005). Kulturwirtschaft in Berlin Entwicklung und Potenziale (Cultural Industries in Berlin Development and Potentials). Berlin: Senatsverwaltung für Wirtschaft, Arbeit und Frauen/Senatsverwaltung für Wissenschaft, Forschung und Kultur

Mulgan, G. dan Worpole, K. (1986). Saturday Night or Sunday Morning? From Arts to Industry New Forms of Cultural Policy. London: Comedia.

Myerscough, J. (1988). The Economic Importance of the Arts in Britain. London: Policy Studies Institute.

O'Brien, J. dan A. Feist. (1995). Employment in the Arts and Cultural Industries: An Analysis of the 1991 Census. London: Arts Council of England.

Organisation for Economic Co-operation and Development (OECD) (1998). Content as a New Growth Industry Working Party on the Information Economy. Paris: OECD.

Organisation for Economic Co-operation and Development (OECD). (1996). The KnowledgeBased Economy. Paris: OECD.

Porter, M. (1990). The competitive Advantage of Nations. New York: The Free Press.

Pratt, A. (2000). New media, the new economy and new space. Geoforum, 31, 425-436.

Pratt, A. C. (2001). Understanding the cultural industries: Is more less?. Culturelink. Special Issue, 51-65.

Republik Österreich vertreten durch den Bundeskanzler, Arbeitsgruppe Weissbuch (1998). Weissbuch.Zur Reform der Kulturpolitik in Österreich. (White Paper. To the Reform of the Cultural Policy in Austria). Vienna: Falter Verlag.

Roodhouse, S. (2002). Creating a Sustainable Culture for everybody.. London: Centre for Reform. Roodhouse, S. (1997). Interculturalism, in Particular the Relationship between Artists and Industrial Imagery. Journal of Arts Policy and Management Law and Society, 27(3), 251270.

Roodhouse, S. (2004). The new global growth industry: definitional problems in the creative industries - a practical approach. Dlm. Roodhouse \& Kelly (Ed.). Counting Culture, Practical Challenges for the Museum and Heritage Sector (pp. 13-31). London: Greenwich University Press.

Ross, A. (2003). No-Collar: The Humane Workplace and Its Hidden Costs. Philadelphia: Temple University Press.

Ryan, B. (1992). Making Capital from Culture. Berlin/New York: Walter de Gruyter.

Sassen, S. (1991). The Global City. Princeton: Princeton University Press.

Sinclair, J. (1996). Culture and Trade: Some Theoretical and Practical Considerations. Dlm. E. G. McAnany \& K.T. Wilkinson (Ed.). Mass Media and Free Trade: NAFTA and the Cultural Industries (pp. 110-127 ). Austin: University of Texas Press.

Smith, C. (1998). Creative Britain. London: Faber and Faber.

The Arts Council of England (1993). A Creative Future: The Way Forward for the Arts, Crafts and Media in England. London: HMSO.

The Arts Council of Great Britain (1985). An Invitation to the Nation to Invest in the Arts, A Great Britain Success Story. London: The Arts Council of Great Britain.

The Arts Council of Great Britain (2003). Artists in Figures: A Statistical Portrait of Cultural Occupation. Research Report 31. London: The Arts Council of England. 
The Arts Council of Great Britain (1988). Better Business for the Art: An Introduction to the Arts Council Inventive Funding Scheme for Arts Organisations. London: The Arts Council of Great Britain.

Thompson, J. (1991). Ideology and Modern Culture. Cambridge: Polity Press.

Throsby, D. (2000). ESconomics and Culture. Sydney: Allen \& Unwin.

Uricchio, W. (2004). Beyond the great divide, collaborative networks and the challenge to dominant conceptions of the creative industries. International Journal of Cultural Studies, 7(1), 79-90.

Weckerle, C. \& Michael Söndermann (2005). Kreativwirtschaft Zürich (Creative Industries Zurich). Zurich: Hochschule für Gestaltung und Kunst.

Wilenius, M. (2004). Luovaan talouteen: Kulttuuriosaaminen tulevaisuuden voimavarana (Towards a Creative Economie: Cultural Know-How as a Future Resource). Helsinki: Edita Publishing.

Williams, R. (1981). Culture. London: Fontana.

Williams, R. (1976). Keywords: A Vocabulary of Culture and Society. London: Fontana. 